\title{
ДОЊИ ТАОР - УТВРДА И ЦРКВА
}

\author{
Дејан Булић \\ Историјски институт, Београд \\ Радивоје Арсић \\ Завод за заштиту споменика културе, Ваљево
e-mail: gavbulic@yahoo.com $\mid$ Претходно саопштење
Примљено: 20. 4. 2021. УДК: 902.2(497.11)"2019/2020”
Прихваћено: 9. 6. 2021. 904:726-27-523.4(497.11)”05”
904:711.559.6"652"(497.11)

\begin{abstract}
Апстракт: У раду су дати резултати сондажних археолошких истраживања мањег двослојног утврђења Град-Таор са касноантичком/рановизантијском компонентом и старијом фазом старијег гвозденог доба. Утврда је имала функцију контроле пута који још од праисторије повезивао долину Колубаре са данашњим Ужицем и Подрињем. У подножју утврде у потпуности су истражени остаци једнобродне рановизантијске иркве, у оквиру које су регистроване три хришћанске сахране, могуће ктиторске породице. Посебно је занимљив гроб оријентаџије север-југ.
\end{abstract}

Кључне речи: Таор, Ваљево,западна Србија, Скрапеж, Повлен, ирква, утврђење, старије гвоздено доба, рана Византија, мајдан сиге

Таор је планинско село града Ваљева. Спада у групу црногорских села, подно Повлена, при извору Скрапежа, над којим доминарју Таорске стене (Павловић 1925, 45; Васовић 2003, 22). Речну мрежу формирају многобројне реке, речице и потоци који се сливају и уливају у Скрапеж. Долина Скрапежа пружа се северозападно-југоисточним (динарским) правацем, тј. паралелна је са планинским венцима и следи раседе или је паралелна са њима (Ршумовић 1980, 127-156). Река Скрапеж, дужине 47,7 км, извире испод Малог и Великог Повлена, а у Ђетињу се улива у Пожешком пољу. Скрапеж, у горњем току позната и по називу Рјечица (Ковачевић-Мајкић 2009, 23-24; 58), у оквиру изворишног дела настаје од више сталних и повремених извора.

Ојконим Таор спада у старобалкански супстрат и препознаје се у неколиким античким топонимима са Балкана (Лома 1997, 21). Звездана Павловић у тумачењу имена ослања се на Скоково мишљење да антички Епидаурум (Epidaurum) садржи назив *taura за брдо, па се отуда у јужнословенској предримској топономастици налази Tauresion > Taor код Скопља, Taurunum, данас Земун итд... (Павловић 2016, 253). 


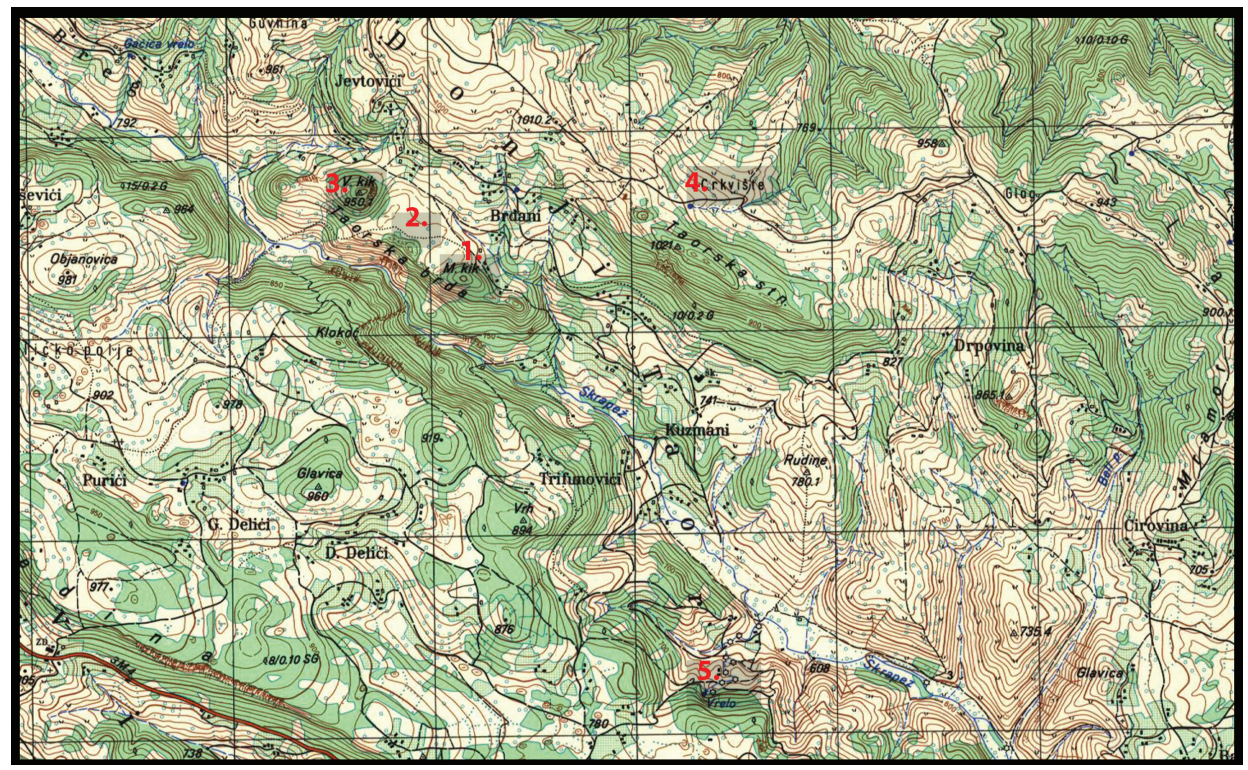

Сл. 1. Позиција локалитета у Доњем Таору: 1. Град - Таор (Мали Кик); 2. Црква;

3. Велики Кик; 4. Црквина; 5. Таорска врела

Fig. 1. Location of the sites in Donji Taor 1. Grad - Taor (Mali Kik); 2. Church;

3. Veliki Kik; 4. Crkvina; 5. Taorska Vrela

У атару села Таор, на Малом Кику, налазе се остаци мањег утврђења, познатог и као Јеринин град, које је својим положајем и изгледом указивало на касноантичку/рановизантијску компоненту, док су постојале индиције и за праисторијски стратум. Локалитет се налази у засеоку Јевтовићи у области Доњег Таора (сл. 1). Брдо Мали Кик је са суседним Великим Киком спојено природним седлом и представља последње у низу брда која се пружају ка Доњем Таору правцем исток-запад. Оба врха су покривена густом шумом, док је једино описано седло покривено ниским растињем. Са седла, односно са западне стране локалитета био је једино и могућ приступ утврди, док су са других страна стрме литице то онемогућавале. Највиша кота утврде је 885 м, што је седло и цркву на њему, удаљене свега стотинак метара, са котом 858, надвисило за непуних 30 м. С јужне стране брда пружа се клисура реке Скрапеж, а са северне стране спушта се пут који води ка Косјерићу, одакле се одваја пут ка Радановцима и кањону реке Забаве.

Остатке града први је запазио етнолог Љуба Павловић: На једном омчитој кречњ ачкој чуичи изнад Скрапежа према Гачовој Стијени је стена названа Таор, са некаквим зидинама, вероватно из оног доба кад је становништво живело по оваквим чукама, ограђено и удружено ради одбране од 


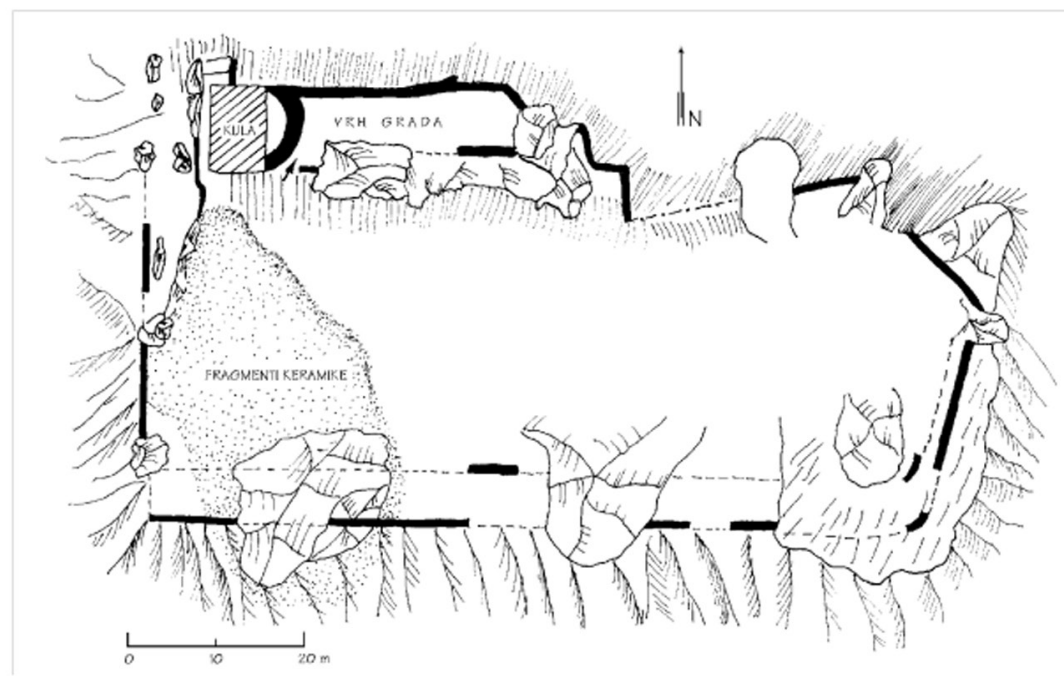

Сл. 2. Основа утврђења Град-Таор (према: Danilović et al. 1995, 310, sl. 3)

Fig. 2. Ground-plan of the Grad-Taor (according to: Danilović et al. 1995, 310, fig. 3)

спољног непријатеља (Павловић 1925, 45). Знатно касније остаци Јерининог града и цркве нашли су се на списку локалитета ваљевског краја, као материјални трагови рановизантијског периода (Јеж и Старовић 1994, 398, лок бр. 117). ${ }^{1}$ Коначно, полазници археолошког семинара Истраживачке станице Петница извршили су 1995. рекогносцирање локалитета, прикупили покретне налазе и направили скицу основе локалитета (Danilović et al. 1995, 309-315). Прикупљени површински налази данас су недоступни, а снимљена основа не одражава затечено стање (сл. 2). Није немогуће да су се постојећи бедеми у међувремену обрушили, али пре ће бити да су неискусни истраживачи донекле исконструисали основу, цртајући оно што је личило на зидове. На то упућују и описана дебљина бедема која варира 30-60 цм, што не може одговарати дебљини бедема, па ни зидовима објеката (Danilović et al. 1995, 310-311). Приликом овог рекогносцирања прикупљени су фрагменти керамичких посуда, фрагменти грађевинске опеке и грумење малтера. На основу анализе прикупљених фрагмената керамике, утврђење је погрешно датирано у период средњег века, односно 13-14. век. (Danilović et al. 1995, 313-314).

\footnotetext{
${ }^{1}$ Локалитет је опредељен на основу извештаја са рекогносцирања др Ђорђа Јанковића 1986. године, када су уочене површинске индикације о постојању зидова и куле на месту где је откривена: Документација Завода за заштиту споменика културе Ваљево.
} 


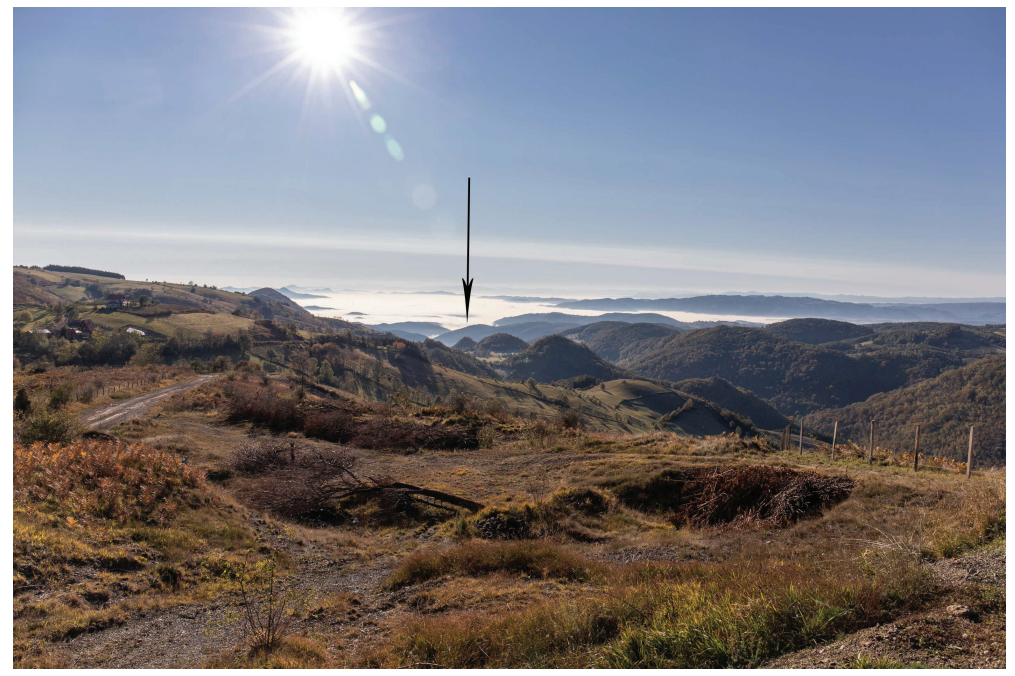

Сл. 3. Град-Таор, поглед са Повлена (са запада)

Fig. 3. Grad-Taor, view from Povlen (from the west)

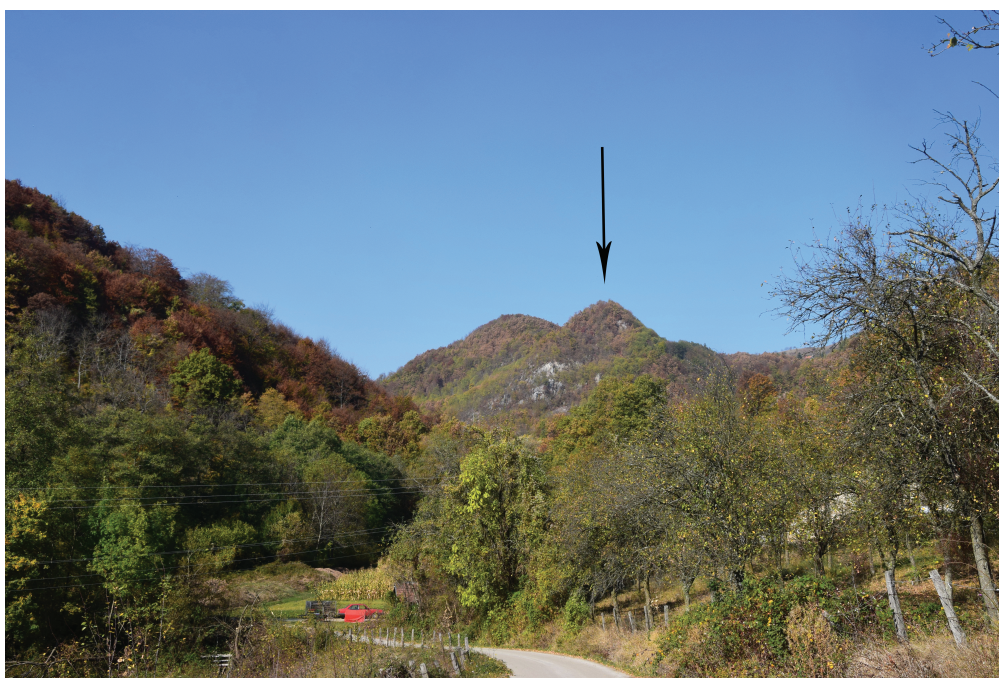

Сл. 4. Град-Таор, поглед из Доњег Таора (са истока)

Fig. 4. Grad-Taor, view from Donji Taor (from the east)

Током друге половине октобра 2019. године изведена су мања сондажна истраживања локалитета Град-Таор (сл. 3-4). Истраживању је претходило крчење платоа на врху брда, где су се очекивали остаци објеката и бедема. Покушаји површинског праћења бедема нису дали никакве резултате, јер су се видљиве камене агломеращије показале или као стене или као осут 

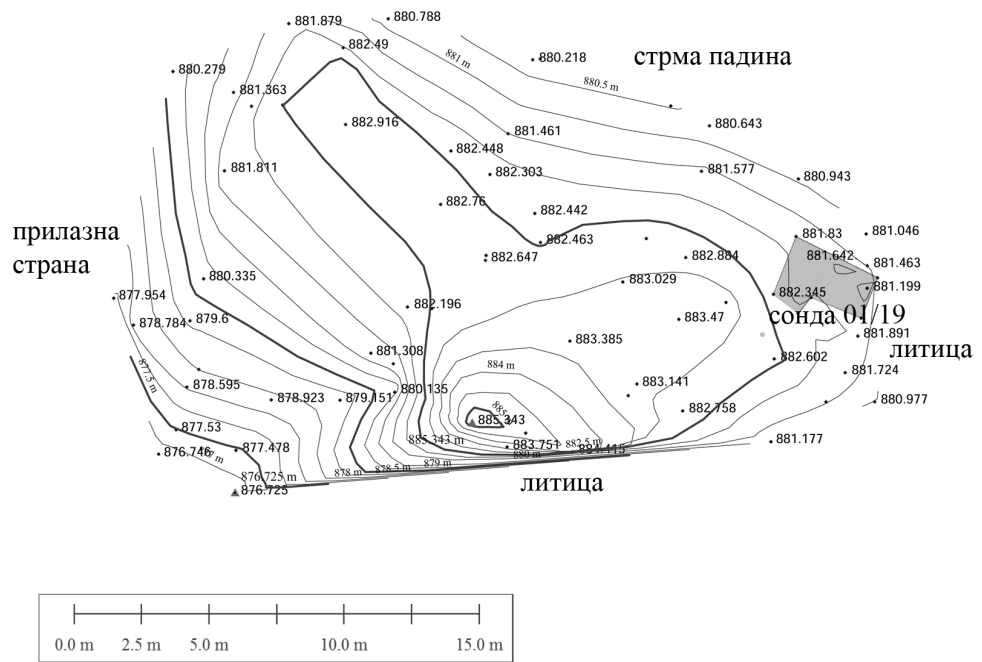

Сл. 5. Град-Таор, ситуациони план

Fig. 5. Grad-Taor, situation plan

камен. На постојање локалитета поред расутог градива, грумења малтера и комада сиге указивали су спорадични површински уломци керамике и један гвоздени фрагментовани део резе (Т. $1 ; 1-3){ }^{2}$

Унутрашњост утврђења чини мањи плато на врху, док се са његове југоисточне, источне и североисточне стране пружају окомите литице, вероватно првобитно затворене бедемима, који су се с временом обрушили (сл. 5). Расположива површина платоа износи око $160 \mathrm{~m}^{2}$, што је омогућавало постојање куле - мотриље, максималних димензија 20 х 8 м. На источном делу овог платоа, готово до саме литице, отворена је сонда 02/19, дужине 3,5 x 1,5 м. Ископ је дужом страном оријентисан правцем исток-запад, са девијацијом од око 20 степени према северу (сл. 6).

Први откопни слој дебљине 0,1-0,2 м чинила је растресита мрка земља, са ломљеним каменом различите величине и неколико отесаних комада сиге мањих димензија. Слој су пратили спорадични налази грнчарије касноантичке/рановизантијске провенијенције и два мања уломка стакла. На десетак центиметара дубине уз јужни профил, односно до максималних тридесетак центиметара уз северни профил констатована је равна испуцала

\footnotetext{
${ }^{2}$ Руководилац археолошких радова био је др Дејан Булић, научни сарадник Историјског института у Београду, а стручни тим чинили су: Радивоје Арсић, археолог конзерватор Завода за заштиту споменика у Ваљеву, и Невена Павловић, археолог из Ваљева.
} 


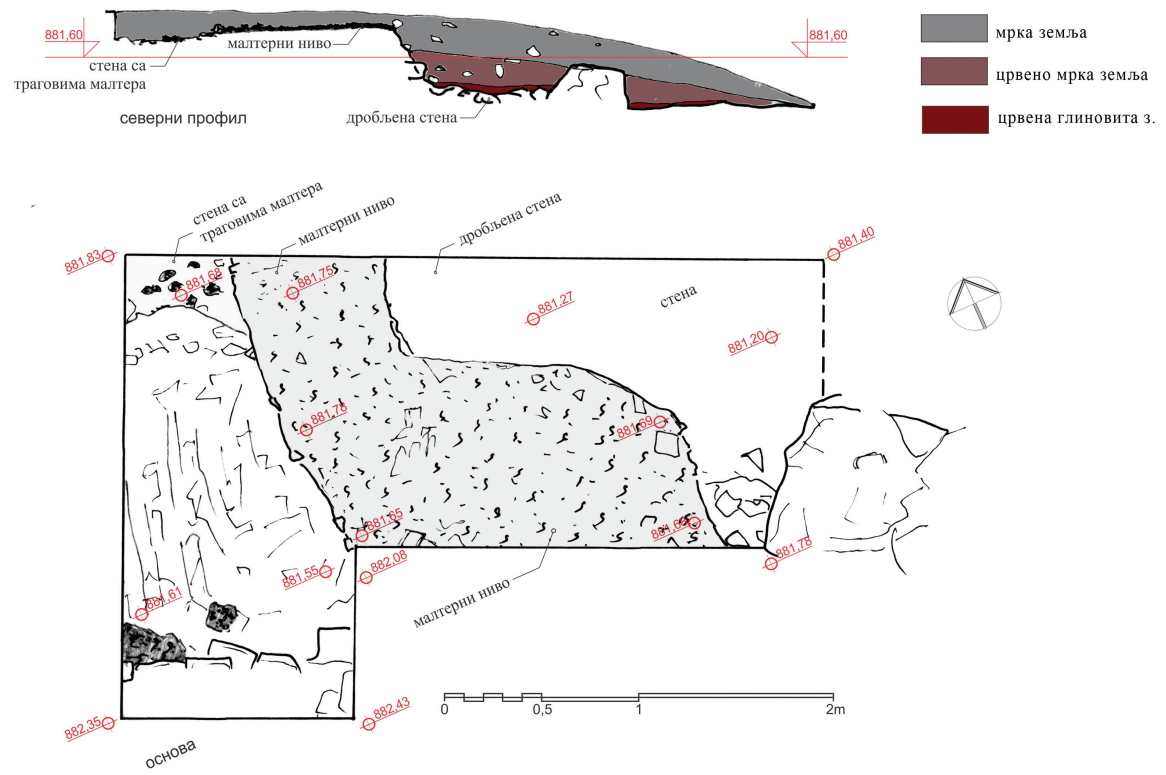

Сл. 6. Град-Таор, сонда 02/19, основа

Fig. 6. Grad-Taor, trench $02 / 19$, ground plan

малтерна површина беличасте боје. Како се малтерни под није сачувао уз јужни профил, тамо је настављено са ископавањем у слоју црвеномрке земље са спорадичним налазима гвозденодопске грнчарије. Уследио је танак слој стерилне црвенкасте глиновите земље са ситним ломљеним каменом над живом стеном.

Исте 2019. године почела су и истраживања цркве, на простору између Великог и Малог Кика, на имању Милана Јефтовића. На површини је била видљива велика гомила камена, овалне форме. Због оријентације исток-запад претпостављено је да је реч о цркви (сл. 7).

Након што су површински испраћени видљива лица зидова, отворена је једна сонда. Ископ је позициониран у источном делу рушевине како би обухватио југоисточни део претпостављене апсиде и део јужног зида. Уклоњен је најпре слој тамномрке земље са крупним каменом (мешавина хумуса и осутог камена са зидова цркве). Уследио је слој чистог шута, односно малтера са бројним квадерима сиге различите величине. Испоставило се да се слој формирао услед рушења некадашње полукалоте апсиде, а на сводарима од сиге били су видљиви трагови малтерног везива. Слој шута лежао је на малтерном поду, док покретних археолошких налаза није било. 


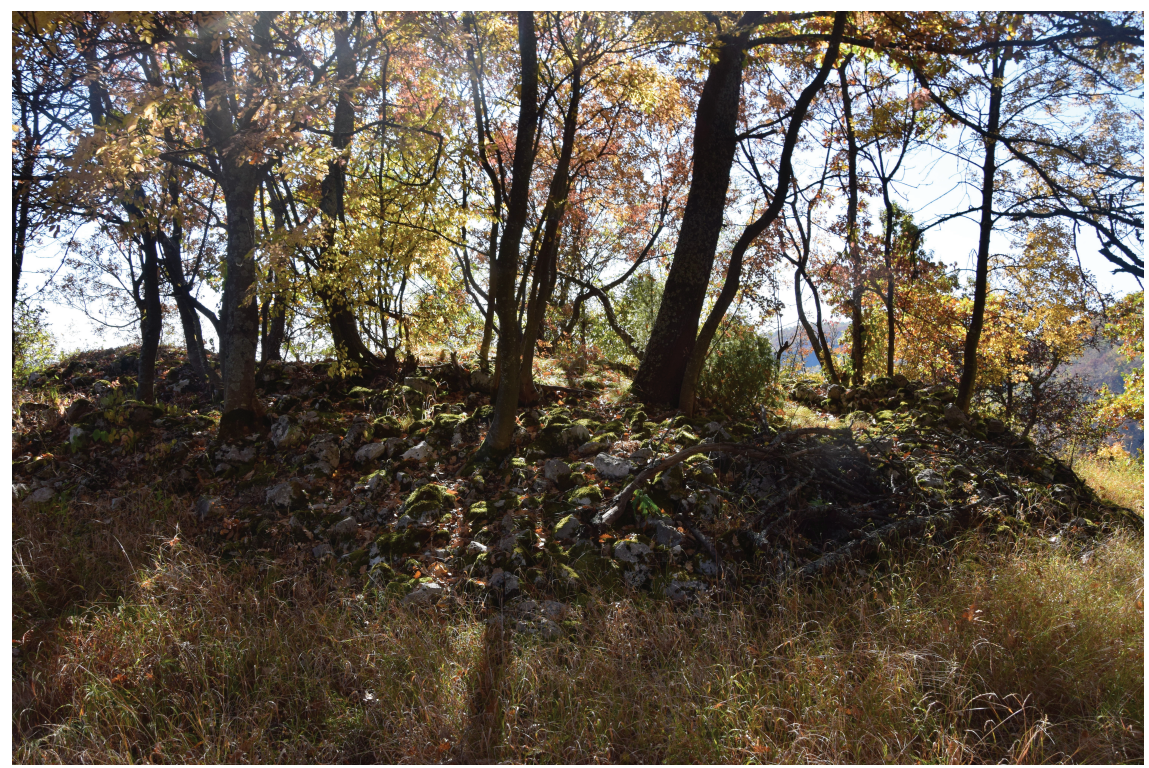

Сл. 7. Црква, изглед пре ископавања

Fig. 7. Church, view before excavation

Након што су потврђене претпоставке о постојању цркве, наредне 2020. године обављено је њено комплетно археолошко истраживање. Црква је истражена, са прекидима, током два месеца, од 24. августа до 24. октобра 2020. ${ }^{3}$ Унутрашњост храма била је подељена на четири сегмента (I-IV), са две осе: север-југ и исток-запад (сл. 8). Оса исток-запад настављала се правцем северног профила првобитне сонде, чиме се овај ископ утопио у сегмент I. На овај начин кроз цркву су добијена два пресека, састављена од профила наспрамних сегмената.

Ископавању је претходила сеча дрвећа са зидова цркве и унутар ње. У површинског слој тамномрке земље, односно хумуса са каменом, дебљине 0,20-0,44 м, пронађен је уломак гвозденог лима и уломак горелог обода зеленоглеђосане посуде (Т. 3/13-14). Уследио је интензиван слоја шута, састављен од ломљеног камена различите величине, дробљеног малтера и комада сиге. Дебљина слоја шута кретала се од 0,10 до 0, 50 м; најинтензивнији је био уз зидове цркве, да би се постепено стањивао ка централном делу, где га није ни било.

\footnotetext{
${ }^{3}$ Средства за истраживање цркве била су делом обезбеђена од пројекта - Сондажно истраживање Ваљева и околине, које на основу конкурса финансира Министарство културе РС, док је средства за радну снагу обезбедио власник имања Милан Јефтовић, на чијем спонзорству овом приликом захваљујемо.
} 


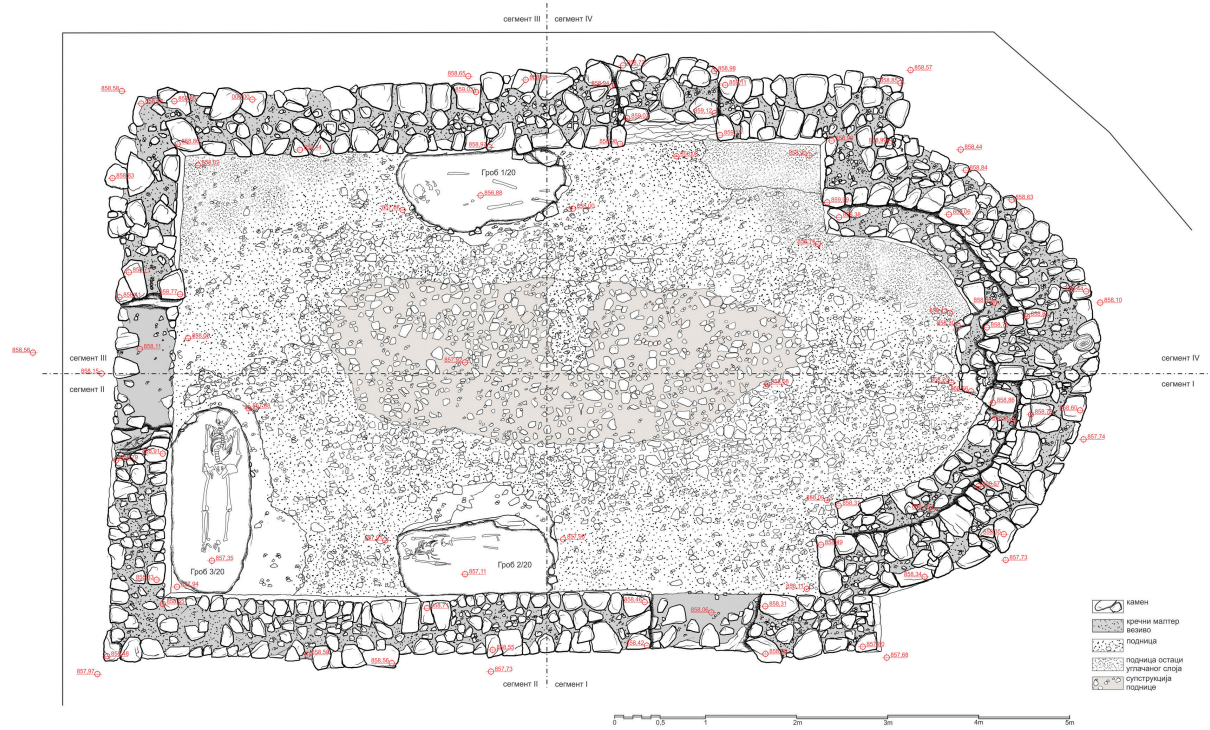

Сл. 8. Црква, основа и профили

Fig. 8. Church, ground plan and profiles

Испод описаних слојева налазио се малтерни под цркве, а тамо где је под био оштећен - камена супструкција пода. Наиме, малтерни под са политуром сачувао се уз зидове цркве, односно тамо где га је шут са обрушених зидова заштитио. У централном делу цркве, где није било шута, под је због изложености атмосфералијама био оштећен и испран, те је остала само камена супструкција пода. На нивоу малтерног пода могли су се местимично уочити мањи трагови паљевине. С временом се над централним делом цркве формирао слој хумуса са каменом (сл. 9-10).

Од покретних налаза, у слоју шута пронађена су два фрагмента животињских костију, фрагмент сечива, уломак стакла и три уломака грнчарије рановизантијске провенијенције, те још неки метални фрагментовани налази (Т. 3/2-6; 10-12).

Осим археолошког ископавања цркве, са спољне стране нивелисан је терен у ширини од 0,5 до 1 м, ради бољег сагледавања спољног лица зида. Нивелација је извршена у површинском слоју мрке земље и у слоју шута. Првобитни ниво терена досегнут је само са јужне стране цркве, где је у шуту откривен део грубо клесаног прозорског оквира од сиге. Из слоја шута у линији улазних врата пронађен је мањи закивак (Т. 3/7), док је још један пронађен у избаченој земљи (Т. 3/8). Коначно са спољне стране апсиде из слоја шута потиче једна тробрида стрелица (Т. 3/ 1). 


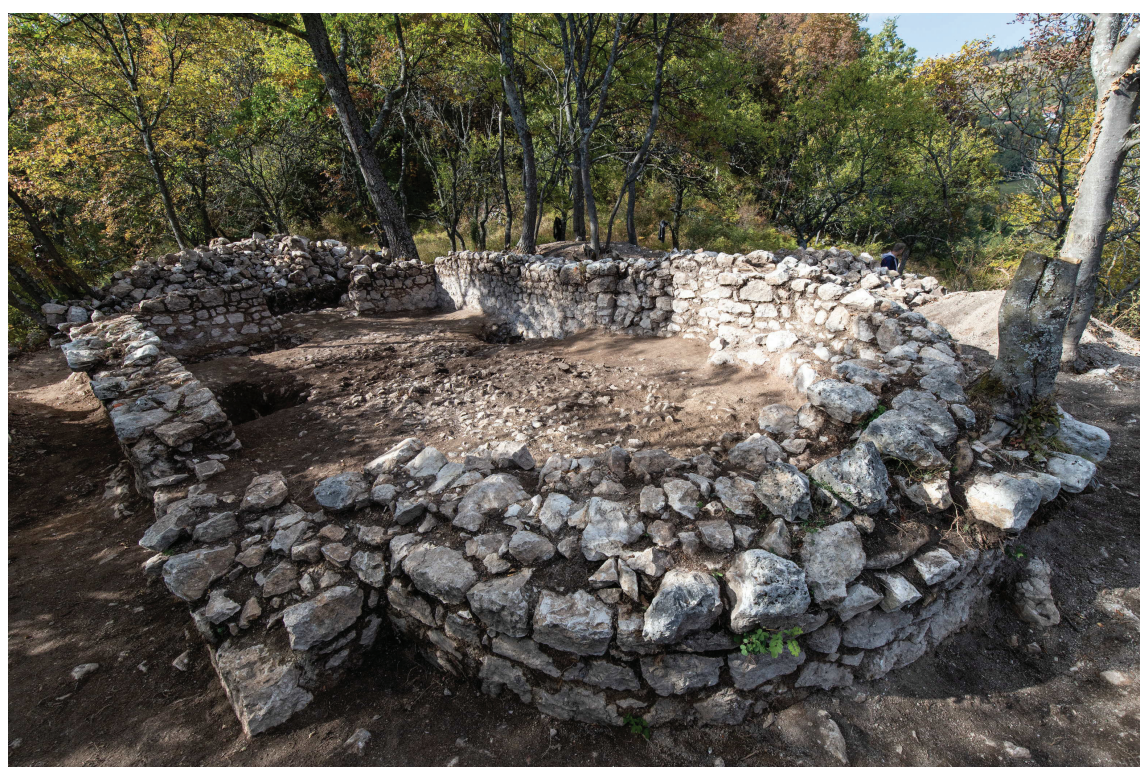

Сл. 9. Црква, снимак са истока

Fig. 9. Church, shot from the east

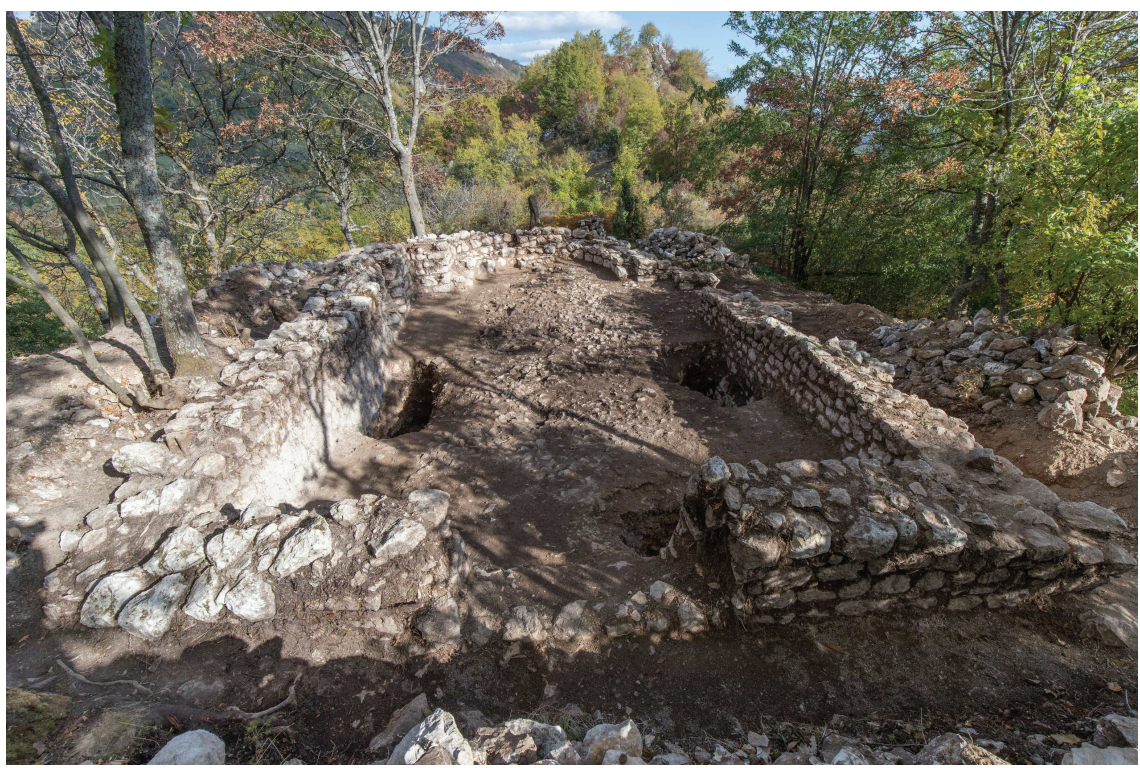

Сл. 10. Црква, снимак са запада

Fig. 10. Church, shot from the west 


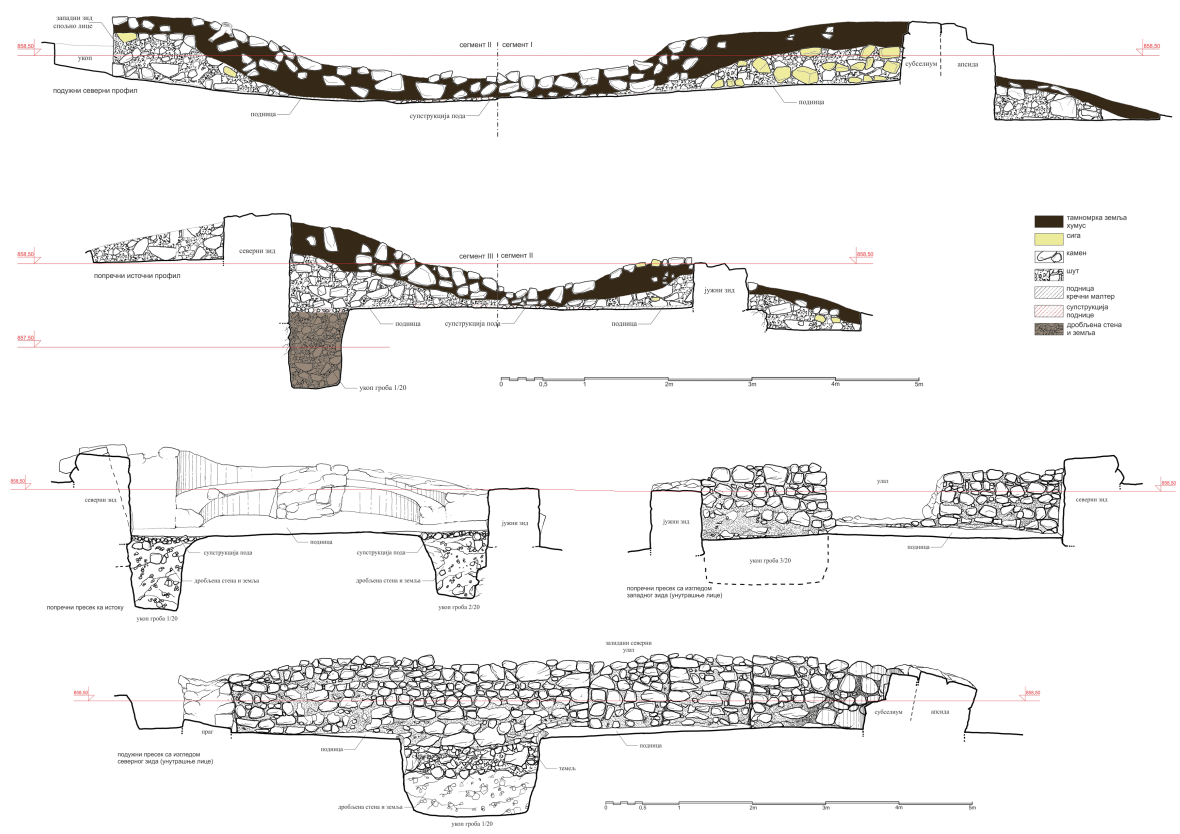

Сл. 11. Црква, попречни и подужни профил и изгледи зидова

Fig. 11. Church, longitudinal and cross-section, and views of the walls

Два метра јужно од јужног зида цркве констатован је један подзид, претпостављамо из времена њене градње, и њиме је спречена ерозија уског платоа са ове стране. Поред овог подзида, ивице заравњеног платоа окружује сухозид, који у облику неправилног троугла затвара расположив простор. Остаци зидова су најизраженији са северне, североисточне и источне стране цркве, док се са јужне стране најмање разазнају на терену. Иако би се могло помислити да зидови представљају оградни зид око цркве, пре би се казало да је реч о каснијој међи којима се штитила драгоцена зараван и који немају везе са подзидом јужно од цркве.

Црква је једнобродна грађевина оријентације И-3 и димензија 10,80 х 6,40 м. Очувана висина зидова је од једног реда камена $(0,20$ м), до максималних 5-6 редова, односно до 1,15 м висине (северни зид). Зидана је од ломљеног камена, везаног беличастим кречним малтером, док је полукалота апсиде изведена у сиги. Измерена дебљина зидова је 0,60 до 0,80 м, што местимично зависи и од компактности зидова (сл. 11).

Од главног улаза у цркву на западном зиду и два наспрамна на јужном и северном зиду, накнадно је зазидан северни улаз (сл. 12). Због оштећења 


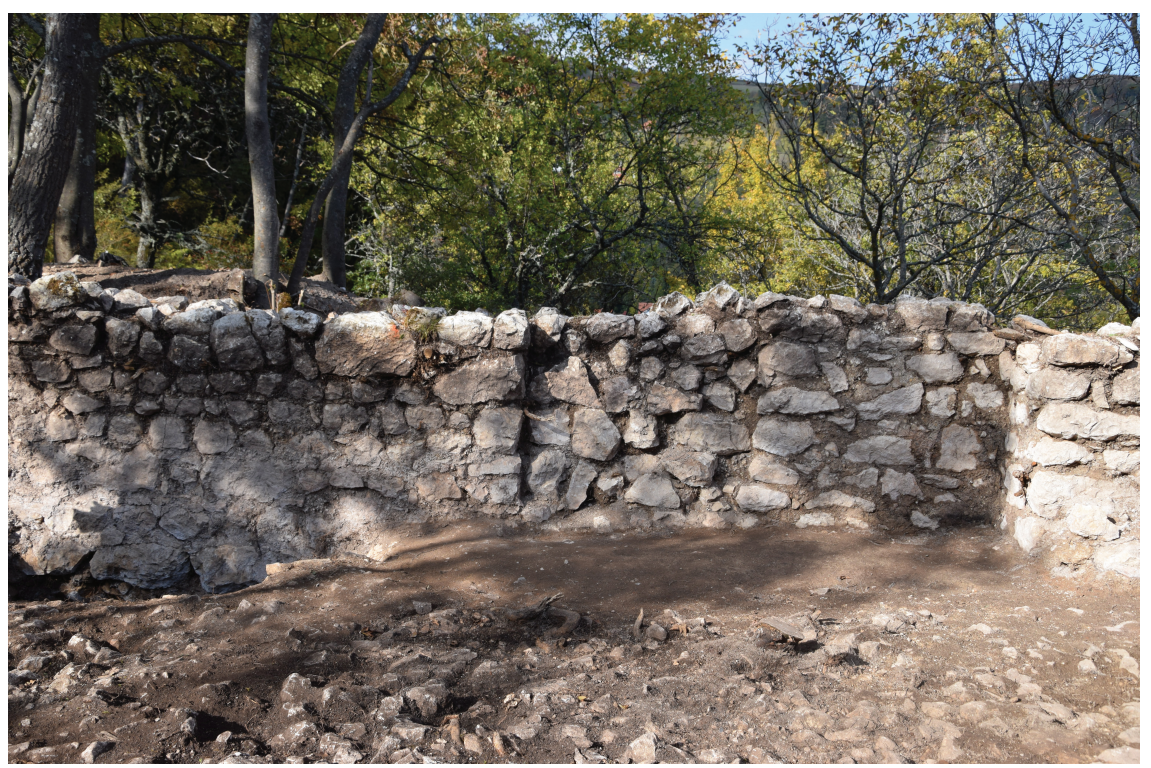

Сл. 12. Црква, зазидани северни улаз

Fig. 12. Church, walled-up northern entrance

довратника и њиховог накнадног нагињања, западни отвор износи између 1,4 до 1,6 м, али је првобитно износио приближно 1,5 м. У испуни отвора западног улаза и непосредно око њега било је више налаза квадера сиге од некадашњег архиволта или надвратника. Ширина наспрамног северног и јужног улаза првобитно је износила 1 м, али је због делимичних оштећења довратника, садашњи отвор 1,1 м. Након што је зазидан северни улаз, његова камена испуна нагнула се ка споља за 15 степени, односно за 0,25 м.

Под је изведен у малтеру, док је његову супструкцију чинио ситнији камен утопљен у кречни малтер.

Унутар апсиде констатован је супселијум ширине 0,35-0,40 м, који прати апсиду у пуном обиму (сл. 13). Према сачуваним котама у односу на под био је подигнут за 0,40-0,45 м. Проширење за епископску катедру позиционирано је у средини апсиде. Очувано је у виду два истурена степеника - први ширине 0,98 м у нивоу супселијума, док се други, ширине 0,80 м, очувао до круништа зида апсиде.

Одсуство налаза кровног покривача указује на дрвени кров на две воде са конструкцијом од дрвених греда. На остатке дрвених конструкција указују местимични налази гарежи на поду цркве. У апсиди пак полукалота је била изведена квадерима сиге, у складу са саставом обрушеног слоја, па препокривена дрвеним кровом. 


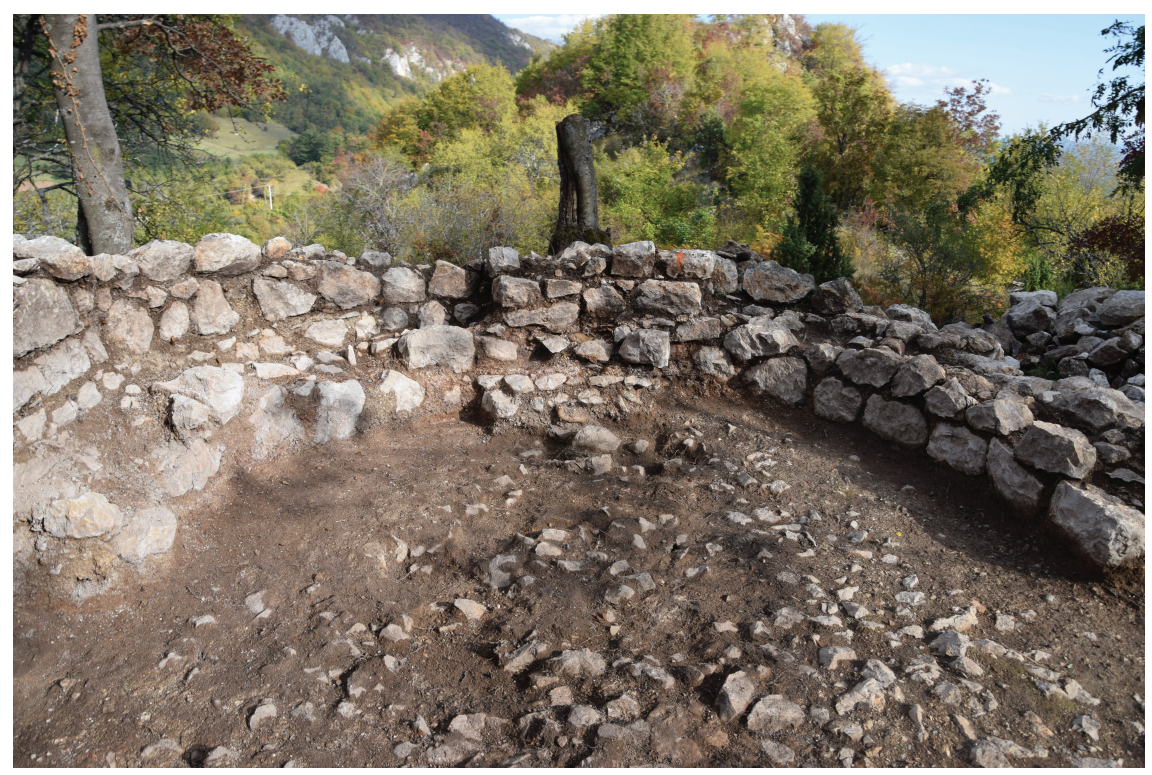

Сл. 13. Црква, снимак апсиде

Fig. 13. Church, shot of the apse

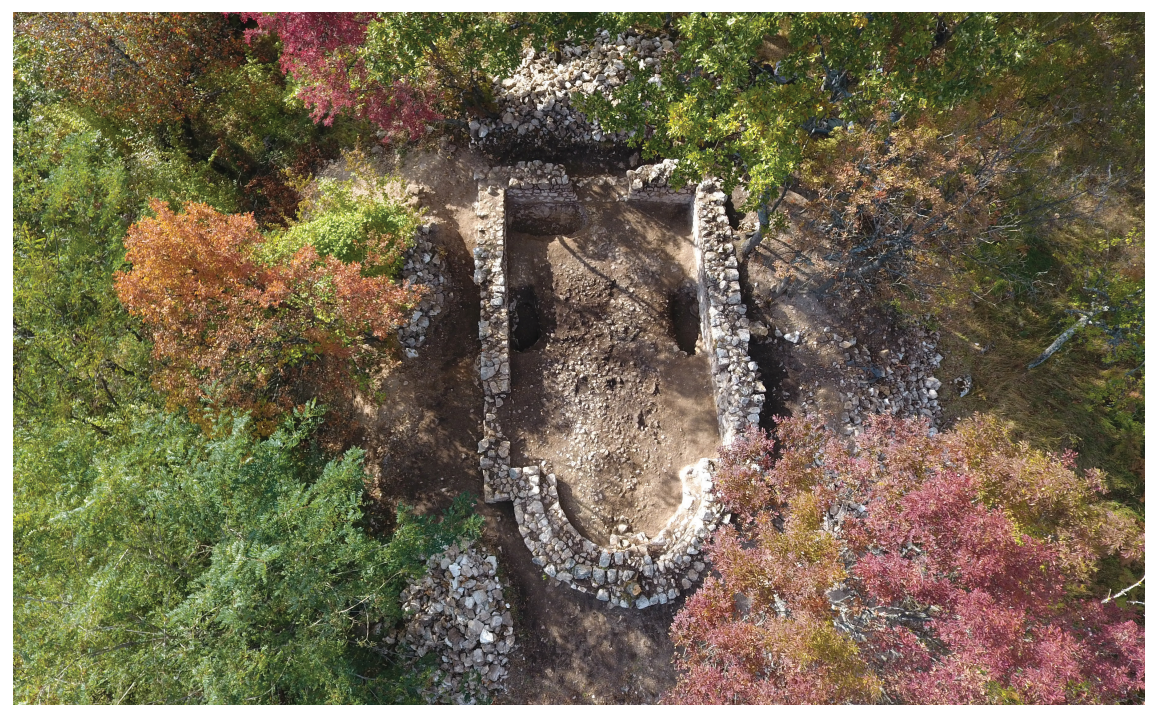

Сл. 14. Црква, основа, снимак дроном

Fig. 14. Church, ground plan, drone shot

Унутар цркве констатована су три укопа приликом којих је пробијен малтерни под (сл. 14). У сваком од ових укопа налазили су се скелетни остаци по једног покојника. 
Први укоп, неправилног правоугаоног облика уз северни зид цркве, испуњен је каменом и шутом, а на његовом дну констатован је гроб бр. 1/20. Скелет одрасле особе у анатомском положају, оријентисан је запад-исток. Лобања је смрскана, лева рука положена је поред тела, док се остаци десне руке нису очували. Карлица је такође здробљена, а прсти шака и стопала тек су делимично очувани. У питању је старија мушка особа, чију старост није било могуће прецизно утврдити услед недовољне очуваности материјала. ${ }^{4}$ Димензије раке укопане у ломљену стену износе 1,90 х 0,65 м. Скелет је укопан у односу на под цркве 1 м (кота 856.88).

Други укоп, правоугаоног облика уз јужни зид цркве, испуњен је каменом и шутом, а на његовом дну констатован је гроб бр. $2 / 20$, који је садржавао скелет детета, у анатомском положају оријентисан запад-исток. Лобања је смрскана, док су остале кости у врло лошем стању. Руке су положене поред теле, карлица је делимично здробљена, а приликом копања уклоњена је десна натколеница. Прсти шака и стопала делимично су очувани. Реч је скелетним остацима инфанта, старости око $6 \pm 1$ година. Раком је пробијен под цркве и она је уклесана у стену. Очувана дужина скелета је 1,15 м, док димензије раке износе 1,80 х 0,67 м. Скелет је укопан у односу на под цркве 0,85 м (кота 857.11). Налаза није било.

Трећи укоп налази се уз западни зид цркве, јужно од улаза. Ископ је такође испуњен каменом и шутом, а на дну укопа констатован је гроб бр. 3/20. Гроб је садржавао скелетне остатке одрасле особе у анатомском положају, оријентисане север-југ. Лобања је очувана, руке су положене поред тела. У питању је индивидуа женског пола, старости 40-50 година. Димензије раке износе 2,10 х 0,80 м. Испуну гроба чинио је шут, а рака је у доњим зонама укопана у ломљену стену. Скелет је укопан у односу на под цркве 0,60 м (кота 857.35). Налаза није било. Занимљива је оријентација овог несумњиво хришћанског гроба. Очито је у овом случају упокојеној или њеној породици било важније да буде сахрањена унутар цркве него сама оријентација гроба.

Према начину извођења појединих елемената цркве, храм се уклапа у манире градње рановизантијске епохе на тлу западне Србије. Грађен је од ломљеног камена, са дрвеном конструкцијом крова на две воде и вероватно без каменог мобилијара. Изгледа су ови елементи цркве у највећем делу били од дрвета. Код великог броја рановизантијских цркава Србије, уобичајен је начин извођења пода цркве малтерним премазом преко камене

\footnotetext{
${ }^{4}$ Антрополошку анализу сва три скелета урадила је антрополошкиња др Наташа Шаркић, Osteo Research, Шпанија.
} 


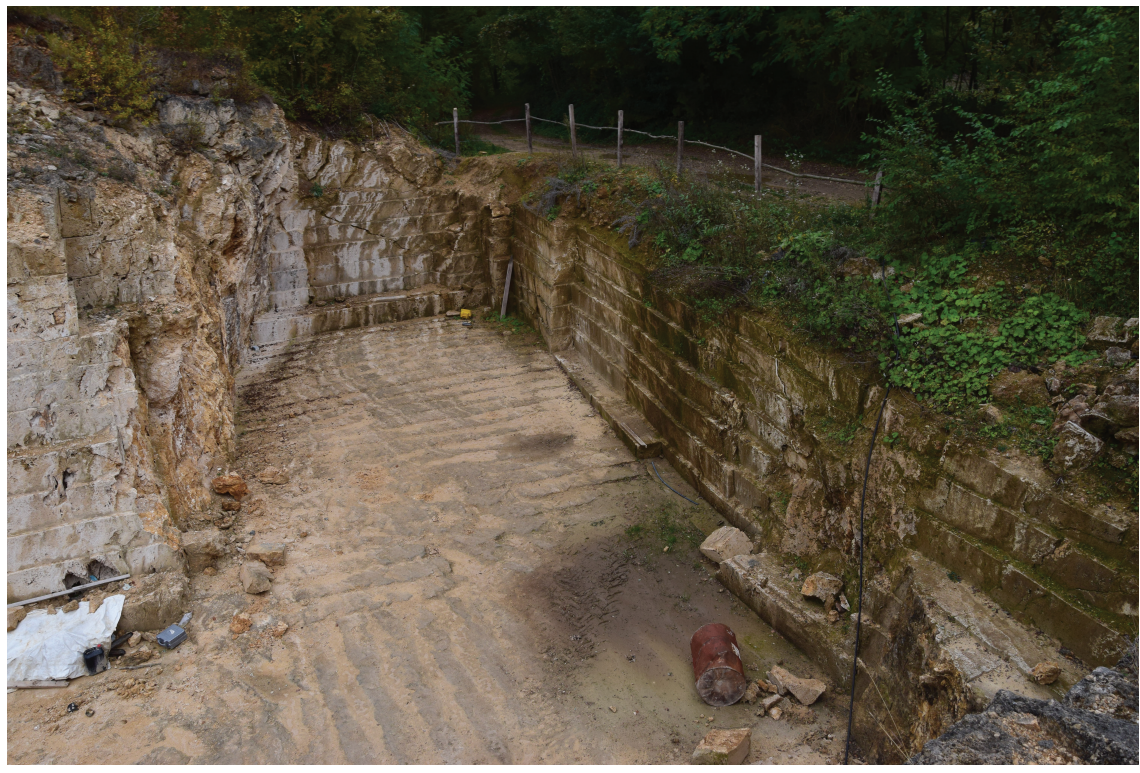

Сл. 15. Таорска врела, мајдан

Fig. 15. Taorska Vrela, mine

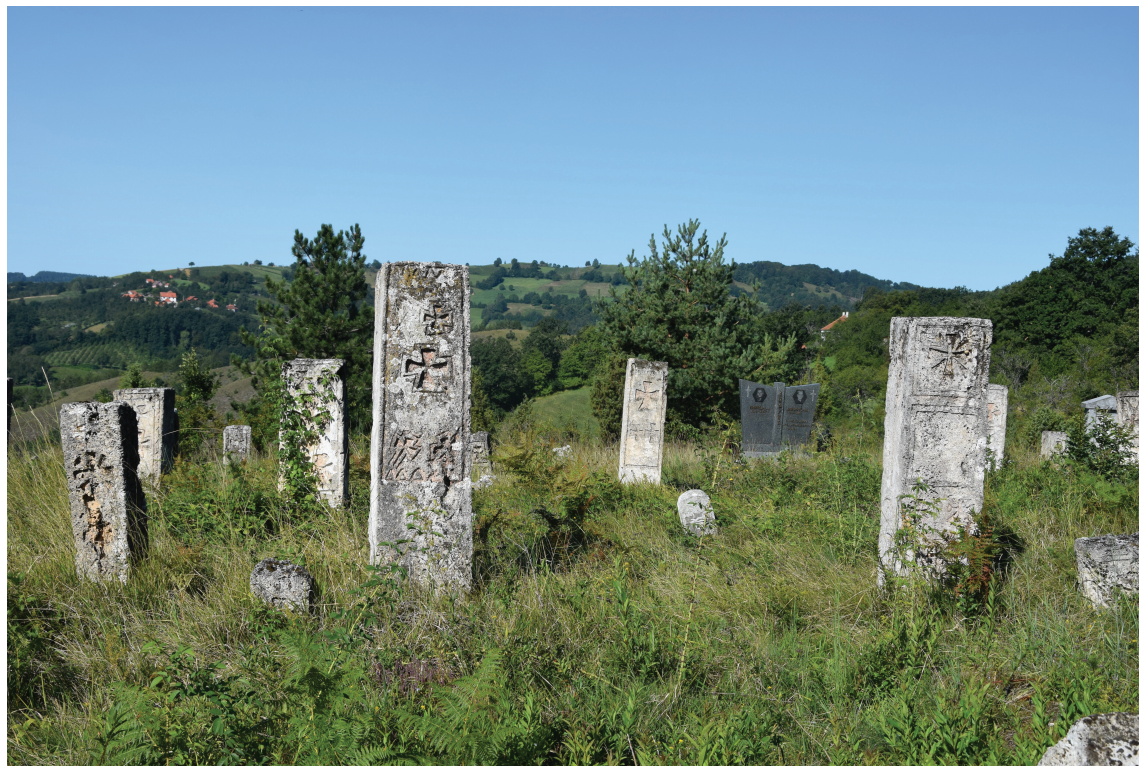

Сл. 16. Надгробни споменици из Таора

Fig. 16. Tombstones from Taor 
супструкције, као и супселијум уз зид апсиде. Просторно и хронолошки најближу паралелу представља црква из утврђења Јеринин град у Бранговићу. Црква подигнута током 6. века идентичне је конструкције и начина израде зидова, подова и апсидалног простора (Мркобрад и Арсић 2004, 93). Једина разлика је у томе што су цркви у Бранговићу дозидане две просторије са северне стране (Арсић et al. 2019, 21). Унутрашњи пречник апсиде од око 2, 9 м код обе цркве се разликује само у неколико центиметара. Слична ситуациja је и у још непубликованој цркви на лок. Град-Градојевић, код Коцељеве. ${ }^{5}$

Као градиво за цркву употребљен је кречњак преузиман ту на лицу места, док су квадери сиге вађени у најближим и добро познатим мајданима код Таорских врела (сл. 15). ${ }^{6}$ Захваљујући овим наслагама Доњи Таор, односно Таорска врела су највећа акумулација бигра у овом делу Србије (Ковачевић-Мајкић 2009, 25-26). Од овог материјала су настали аутентични надгробни споменици овог краја (сл. 16), а као материјал за изградњу надгробних споменика сига се користи од средњег века. Тако је забележена велика некропола од сиге на лок. Паљевина - Сеоско гробље у селу Стојићи (Зечевић 2005, 164-165), док су поједини надгробници били израђени од сиге и на некрополи Гробљице у Косјерићу (Булић 2016, 183-204).

\section{Археолошки материјал}

Археолошки материјал утврђења показује двослојност локалитета. Млађем културном касноантичком или рановизантијском хоризонту припадају површински налази (Т. 1/ 1-3), као и налази над малтерним подом објекта у сонди 1/19 (Т. 2/ 1-12). Од површинских налаза, поред грумења малтера, пронађен је уломак грнчарије израђене на брзом витлу, мањи комад лепа и фрагментована гвоздена шарка. Унутар сонде 1/19 над нивоом малтерног пода пронађен је део античке опеке (Т. 2/ 11), неколико уломака кухињског посуђа израђеног на витлу (Т. 2/ 6-7, 10, 12), као и пет уломака стакла (Т. 2/ 1-5). Налази су малобројни и недовољни за прецизну типолошку и функционалну класификацију грнчарије и датирају се оквирно на основу израде.

\footnotetext{
${ }^{5}$ Археолошка истраживања цркве током 2019. и 2020. године водили су аутори овог текста.

${ }^{6}$ Главну хидролошку одлику у сливу Скрапежа чине бројни извори и врела, међу којима су најзначајнија Таорска врела, која се налазе на десној долинској страни средњег тока Скрапежа. Припадају крашким врелима, велике издашности, захваљујући великој области коју дренирају.. Извиру испод вертикалног кречњачког одсека високог 35-40 м (Ковачевић-Мајкић 2009, 52 53). Вода садржи знатне количине растворених кречних материја и приликом отицања таложи велике количине бигра захваљујући каскадама и водопадима насталим услед селективне ерозије, који се завршавају водопадом на ушћу Врелског потока у Скрапеж (Васовић 2003, 73-80).
} 
Прозорском стаклу, које је уобичајен налаз на касноантичким и рановизантијским утврђењима, припадају три уломка. Уломак стакленог пехара, издигнутог конкавног дна од светлозеленог стакла има аналогије у рановизантијским налазима са Градине на Јелици, датиран у 6. почетак 7. столећа (Милинковић 2017, 159. кат. бр. 250-252). Уломак је сличан налазу из цркве. Делу стаклене посуде конкавних зидова припада и бледожућкасти уломак израђен техником слободног дувања (Т. 2/4).

Иако је материјал недовољно речит, смештамо га оквирно у време касне антике, када је и подигнута кула мотриља, док је време страдања утврде истовремено са страдањем цркве подно утврде, односно крајем 6. или почетком 7. столећа.

Праисторијским траговима датираним оквирно у старије гвоздено доба припадају ситни уломци из слоја црвеномрке земље над живом стеном (Т. 1/ 4-7). Слој је испод малтерног пода, из затворене целине, чији сви налази припадају праисторијском хоризонту. То су мали атипични уломци рађени руком црвеномрке боје. Два уломка носе трагове украшавања - један има сноп хоризонталних линија, а други линеарни украс. Осим тога два праисторијска уломка нашла су се у слоју са рановизантијским материјалом над малтерним подом (Т. 2/ 8-9). Налази по начину израде одговарају оквирно калакача фази босутске културе, аналогно налазима из Бранговића (Арсић et al. 2019, 30).

Из цркве и непосредно око ње потиче известан број налаза. Највећи број је из слоја шута. Међу налазима су три уломка грнчарије израђене на брзом витлу (Т. 3/ 10-12), један уломак дна стакленог пехара (Т. 3/5 ), док остало чине метални налази (Т. 3/ 1-4; 6-9).

Два уломка грнчарије, са видљивим траговима витла споља и изнутра, имају бледожуту фактуру, идентичну дну суда са тврђаве. И уломак стакленог пехара, издигнутог конкавног дна од светлозеленог стакла, налик примерку са утврђења, има аналогије у рановизантијским налазима са Јелице датираних у 6. и почетак 7. столећа (Милинковић 2017, 159-161. кат. бр. 250-252, 254, 260-261). С обзиром на налаз унутар цркве, вероватно је коришћен као кандило.

Из површинског слоја мрке земље поред уломка гвозденог лима потиче и уломак обода грнчарије, који је горео, али се ипак може уочити да је припадао зелено глеђосаној посуди типичној за касну антику или рановизантијски период (Цвјетићанин 2016, 155-157; Милинковић 2017, 214215). Између касноантичке и рановизантијске керамике најчешће је тешко уочити разлику, јер неретко облици припадају истим типовима посуђа или истим радионицама. 
Остали налази припадају хронолошки неосетљивом материјалу или атипичним фрагментима: уломак гвозденог лима и лима непознате легуре (Т. 3/9, 13); мања метална кланфа (Т. 3/ 6); два фрагментована гвоздена кованика (Т. 3/2-3), део гвозденог сечива (Т. 3/ 4) и два мања гвоздена закивка са широким заобљеним главама, који су могли бити део неке дрвене кутије или мобилијара (Т. 3/ 7-8).

Најинтересантнија је делимично оштећена гвоздена тробрида стрелица са трном за насађивање округлог пресека, која сведочи о бурним временима страдања утврде и цркве (Т. 3/1). У старијој литератури се сматрало да су тробриде стрелице са трном номадског порекла, да су примљене у контакту са Хунима, те да се датују у време хунског продора у Подунавље (Mrkobrad 1980, 52). Међутим, ове стрелице континуирано су се користиле кроз дужи период. У два касноантичка гроба (бр. 123 и бр. 97) некрополе Слог у Равни (Timacum Minus), датована у другу фазу некрополе, односно 380-410. годину, пронађене су тробриде стрелице (Petković i Miladinović-Radmilović 2014, 125 , T. 6/5 і T. 7/6). Из гроба 2/2006, датираног у године 420/430-450, са четврте некрополе Сеобе народа из Сингидунума, потиче више налаза тробридих стрелица заједно са остацима тоболца (Ivanišević i Kazanski 2007, 122-125, 134).

Међу многобројним тробридим стрелицама проналаженим у истраживаним римским војним логорима у Србији или на другим локалитетима, најсличнији нашем примерку јесте стрелица са локалитета Салдум-Градац, датирана у 4-5. век (Vujović 1998, 109, Т. 33/10). Касније се датују тробриде стрелице из Јакова као гепидски налаз из периода 454-568. године (Mrkobrad 1980, 52, Т. 42/ 14), или у време Авара првог таласа (567-626) из Бузета и Врбаса (Mrkobrad 1980, 99, Т. 81/11, 13).

На рановизантијским локалитетима дуж десне обале Дунава пронађено је 13 стрелица овог типа, различитог облика и величине. На основу степенастог прелаза у трн округлог пресека издвајамо примерке са лок. Љубичевац-Гламија или Ушће Слатинске реке, те Дијане (Špehar 2010, 129-130, T. 39/696, 703-704). Ипак, наш примерак највише сличности има са стрелицом са Јелице, датираном у крај 6. и почетак 7. столећа, због идентичног степенастог прелаза ка трну округлог пресека. (Милинковић 2015, 155. сл. 108; Милинковић 2017, 196, кат. бр. 386).

Сличности материјала из цркве и тврђаве, као и међусобни положај, само указују на њихову повезаност и хронолошко синхроницитет. Црква је датирана на основу архитектонских карактеристика и градње, те на основу покретног материјала. Тробрида стрелица и местимични трагови паљевине на поду цркве указују на насилан прекид живота цркве и вероватно утврде. Индиректно на пожар указују трагови горења на појединим уломцима керамике (Т. 2/12). 


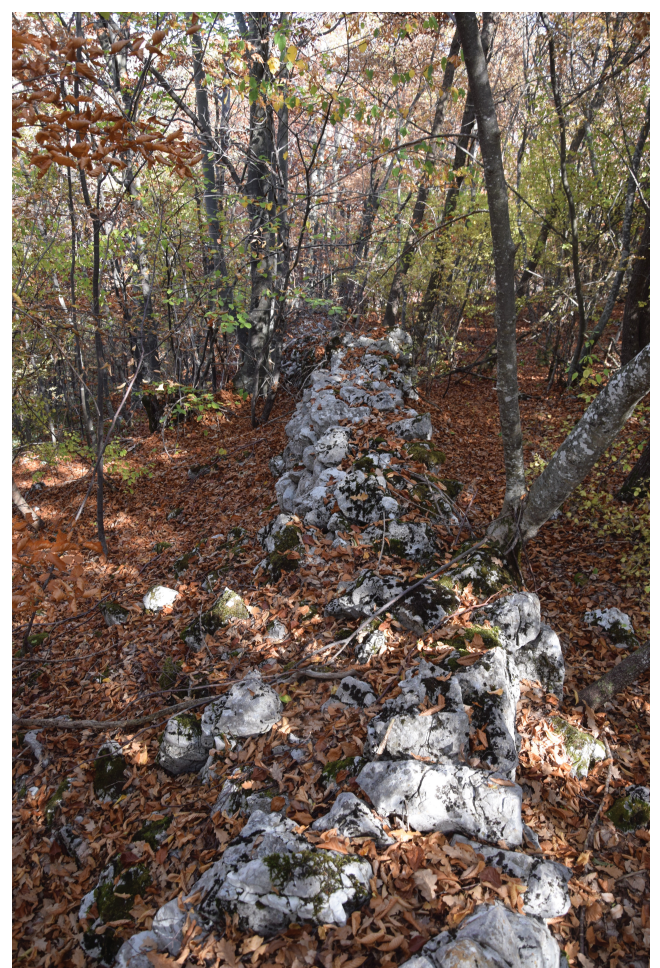

Сл. 17. Велики Кик, сухозид

Fig. 17. Veliki Kik, dry stone wall

$* * *$

На суседном брду Велики Кик, са западне стране локалитета, констатован је сухозидни бедем који се пружа правцем север-југ (сл. 1; 17). Бедем је затварао западни, уједно и једини прилаз врху брда и само преко улазног отвора ширине 2,60 м омогућавао је прилаз платоу. Од улаза сухозид се пружао ка југу у дужини од 8-9 м, односно ка северу у дужини од 40 м, све до северне и јужне стрме стеновите падине брда. Максимално очувана висина бедема је 0,90 м, колико је износила и његова ширина, односно око 3 стопе. Постојање овог сухозида навело је младе истраживаче из Петнице да помисле да се и овде налазило утврђење (Danilović et al. 1995, 310). Плато обрастао у шуму, са источне стране се сужава и завршава стеновитим гребеном, одакле се стрмо спушта ка превоју са црквом.

На платоу нема видљивих трагова становања, али је поље подно западне стране повољно за насељавање и пољопривреду. С друге стране поља је још једно стеновито брдо, за које мештани држе да такође има остатке утврђења, што смо приликом његове проспекције оповргли. 


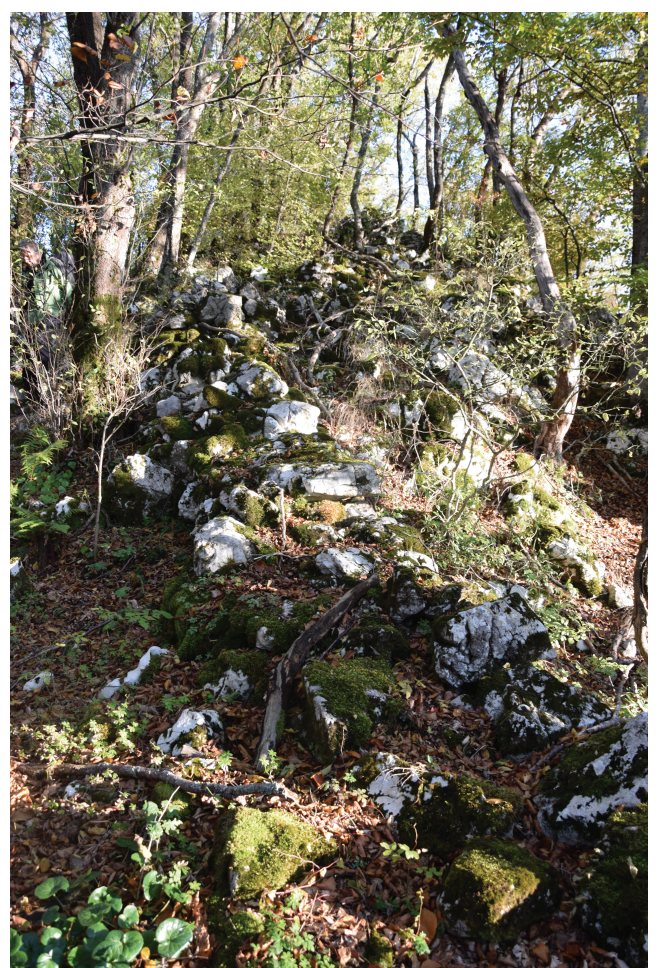

Сл. 18. Таорска стена, сухозид

Fig. 18. Taorska Stena, dry stone wall

У Горњем Таору, подно Таорске стене и Камене косе, крај некадашњег војног пута забележено је постојање Црквине са јаким извором (Павловић $1925,45-46)$. На локалитету - уз који са југоисточне стране протиче поток - нема видљивих трагова било каквог објекта, и само један савремени гроб и поломљени усадник од сиге указују на сахрањивање (Т. 1). Уз поток постоји један већи укоп, а на падини североисточно од Црквине остаци недефинисаних закопина, те би, под условом да је постојала, црква могла бити у окружењу, али не на позицији коју мештани показују.

Коначно, приликом проспекције гребена Таорске стене, данас потпуно пошумљене, уочен је низак сухозид (сл. 18). Сухозид се пружа десетинама метара дуж гребена, чије стране местимично стрмо падају, нигде не скреће и не затвара никакву површину. Његова висина је мања од једног метра, дебљина је такође невелика, док мештани не памте време његове градње, нити знају његову сврху. Наша је претпоставка да је дуж гребена сухозид имао улогу грудобрана, током Другог светског рата, или евентуално Великог рата, одакле се могло дејствовати дуж пута који се с Повлена спу- 
штао у Косјерић. На више места дуж висова на Мравињцима, изнад Забаве и Малог поља, има материјалних трагова војних положаја из маја 1944. године, као и трагова тешких борби између ЈВО и НОВЈ, који се подударају са ратним дневницима (Morača 1962, 228).

Разматрајући функцију утврђења полазимо од податка да је Тахор (=Таор) био рудник железа 1536. године у Смедеревском санџаку. На име десетка од гвожђа које производи раја давало се годишње 1000 акчи, а у селу су радила два самокова (Аличић 1985a, 252). У каснијим пописима 1560. и 1572. нема назнака да је у селу био рудник (Аличић 1985b, 127; 325-326), али као планински крај погодан за сточарство, у пописима овчарине и торовине Ужичког кадилука 1596. године уписано је одсеком у рукама села 399 оваца (Амедоски и Булић, 2020, 38). Можемо да претпоставимо, да су се два самокова - постројења која су користила водену енергију како би покретала велике чекиће којима се дробила и уситњавала руда, или обављали ковачки послови - налазила на реци Скрапеж. Најповољније место су била Таорска врела, где је у прошлости било много воденица, што потврђује велики проток воде, који су самокови управо и тражили.

Ипак, рудник је могао радити и нешто раније, јер у попису Смедеревског санџака за 1476. годину недостаје неколико првих листова са пописом султановог хаса, самим тим и подаци о активним рудницима. Наиме, године 1476. у селу Парамуну и у селу Сеча Река наводи се ковач, за којег се може претпоставити да је опслуживао самоков који је био у закупу кнеза Малоге (Аличић 1984, 31-32, 55). Овај самоков се може повезати са неким рударским активностима у околини.

Упркос помена рудника у османским пописима, за сада се не располаже материјалним траговима о експлоатацији и преради руде на простору ближе околине Таора, а детаљнија теренска археолошка испитивања нису вршена. Међутим, на територији суседног села Радановаца, рудно лежиште извора Лајковаче оцењено је као перспективно са становишта бакроносности (Општина Косјерић 2018, 47).

Ипак, мања фортификација на Таору најпре се може посматрати у контексту путне мреже. Археолошким истраживањима документовани су директни и индиректни показатељи постојања старог пута, који је из Ваљевске котлине водио преко Повлена, на једну страну ка Чачанској и на другу страну ка Ужичкој котлини. На пут у општим цртама, али и на његову старину указао је Љуба Павловић (Павловић 1907, 562), позивајући се на њега 


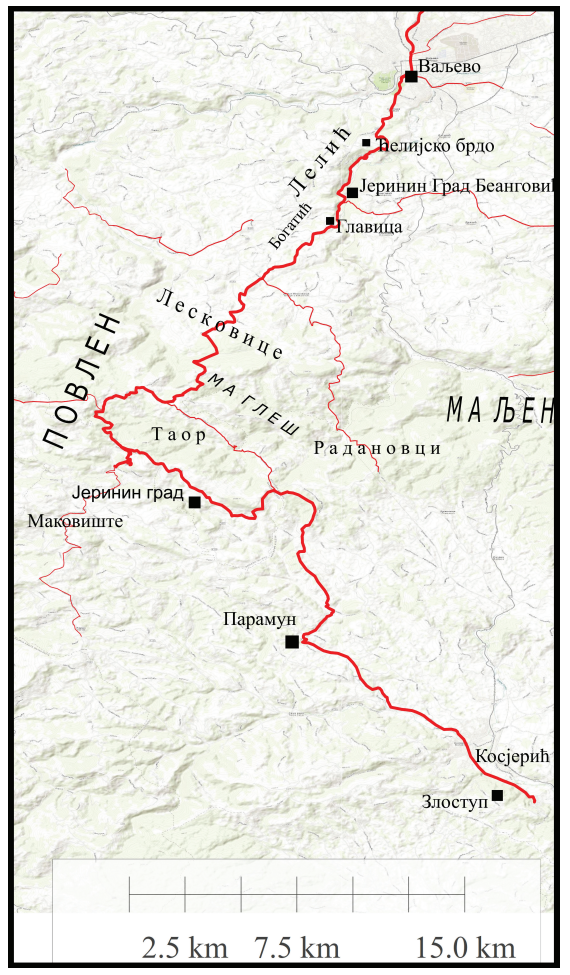

Сл. 19. Траса пута

Fig. 19. Road route

и Гавро Шкриванић (Шкриванић 1974, 111-114), те коначно и Марија Исаиловић, описујући га као римску комуникацију која спаја ужичку котлину са Ваљевом (Исаиловић 1989, 194). Трасу овог пута, према лингвистичким истраживањима, подржао је и Александар Лома, по коме су дуж те трасе расути археолошки и ономастички трагови веће старине него што их налазимо другде у овој области (Лома 1997, 21).

Данас се линија пута највећим делом може доста прецизно реконструисати захваљујући бројним налазиштима дуж његове трасе. Уз трасу пута налази се више утврђења са културним хоризонтом старијег гвозденог доба и касноантичким/рановизантијским стратумом, често и хоризонтом раног средњег века. Пут се из колубарске долине и Ваљева пео поред Баира ка Попарама, долазио до Лелића, а затим пролазио поред Ћелијског брда, где се налазило мање утврђење, које је управо обезбеђивало овај део комуникације (сл. 19). Одавде се спуштао серпентином у кањон Градца поред данашњег манастира Ћелије, одакле је даље ишао поред утврђења у Бранговићу, највећег по габаритима, чија је првобитна функција изгледа повезана са путном 


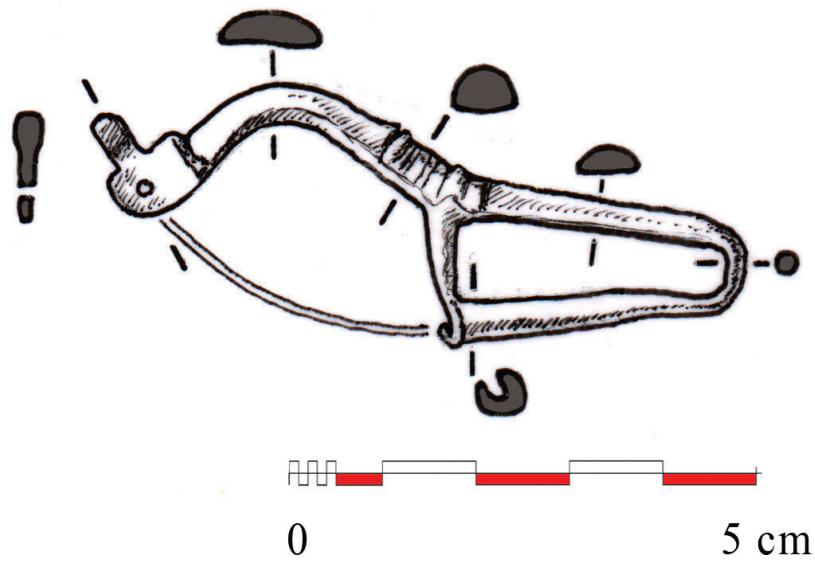

Сл. 20. Цртеж фибуле

Fig. 20. Drawing of a fibula

комуникацијом која је пролазила кроз кањон Градца (Арсић 2011, 71-73). Пут се на Повлену вероватно рачвао, па се један крак преко Пашине равни и Трешњице или преко Зарожја спуштао у долину Дрине. Други крак водио је преко Парамуна и Злоступа преко Карана ка Ужицу и даље, а од ове трасе одвајао се и крак ка Пожеги и Чачку. Трећи крак је водио преко села Маковишта и Варде, преко Јакаља ка Дрини (Максимовић и Војновић 2017, 55-56).

Највидљивији и најбоље очувани трагови пута налазе се на местима где траса напушта кањон Градца, поред манастира Ћелије и у Богатићу, где су видљиви усеци у стенама, подзиде од камена и озидани пропусти за воду. Једини налаз који директно указује на старост комуникације јесте бронзана лучна фибула са посувраћеном стопом из рановизантијског доба (сл. 20), случајно откривена у калдрми пута испод локалитета Главица-Богатић (Арсић et al. 2019, 9).

Ако се имају у виду бројне фортификације на овој комуникацији, може се претпоставити да је сам пут имао много већи значај него што то изгледа на први поглед. На већини ових утврђења присутни су налази из старијег гвозденог доба. На утврђењу у Бранговићу функционисало је велико насеље током старијег гвозденог доба, а исти временски хоризонт имају и утврђења: Ћелијско брдо, Град-Таор, Злоступ, док за утврђење у Парамуну немамо податке. Одабир ових стратегијских позиција и важност пута потврђења је подизањем зиданих утврђења у позној антици и раној Византији, као и тиме да су их у раном средњем веку (9-11. век) користили Срби (Ћелијско брдо, Бранговић). Касније комуникација губи на значају, у позном средњем веку нема утврђења дуж ове комуникације и једино манастир Ћелије указују на његову важност. Ипак, иако периферан, пут није потпуно запостављен и користи се и данас. 
Поменутом распореду утврђења хипотетички би одговарало постојање још неке до сада неоткривене, мање фортификације на овој траси пута. Чини се да је распон пута између Таорског града и Јерининог града око 30 км сувише велик и да би у средишњем делу трасе могла постојати још нека контролна тачка, осматрачница или мања утврда.

Александар Лома је претпоставио да би се име Повлена могло довести у везу са именом кастела који је обновио византијски цар Јустинијан у првој половини 6. века, а које Прокопије бележи као Па́ $\mu 1 \lambda \iota \varsigma$, искварено од По́и $\lambda \lambda$ ivos = лат. Paullinus. Могуће је да се словенско Повлен заснива на већ латинском називу *Paul(l)inus mons - „Павлова гора”, и да се планина могла назвати по Св. Павлу, ако му је била посвећена нека важнија црква на њеном подручју, али и по неком човеку који се звао Paulus (Лома 1997, 22).

Делује примамљиво претпоставка да је црква у Таору била посвећена Св. Павлу те да се с временом име проширило на целу планину Повлен. Тада бисмо лако објаснили инсистирање на сахрани унутар цркве, по цену нехришћанске оријентације. Ипак, чини нам се да цркву, којој планина дугује име, морамо потражити на некој другој локацији са грађевином већих габарита и под неким већим утврђењем. Наша црква сеоског карактера осликава поодавно учвршћено хришћанство, присутно и у најруралнијим подручјима.

Можемо да закључимо да је тврђава страдала заједно са црквом. Највероватније да је овај простор напуштен или је досељена нехришћанска популација, због чега до обнове цркве никада није дошло, а традиција о постојању сакралног места се губи. Последњи припадници те првобитне популације, можда чланови ктиторске породице, сахрањени су у цркви убрзо након њеног рушења.

\section{БИБЛИОГРАФИЈА}

Аличић, А. 1984. Турски катастарски пописи неких подручја западне Србије, 15. u 16. век I. Чачак: Историјски архив - Краљево: Међуопштински историјски архив; Титово Ужице : Историјски архив.

Аличић, А. 1985а. Турски катастарски пописи неких подручја западне Србије, 15. u 16. век II. Чачак: Историјски архив - Краљево: Међуопштински историјски архив; Титово Ужице : Историјски архив.

Аличић, А. 1985b. Турски катастарски пописи неких подручја западне Србије, 15. u 16. век III. Чачак: Историјски архив - Краљево: Међуопштински историјски архив; Титово Ужице : Историјски архив. 
Амедоски, Д., Булић, Д. 2020. Узгајање ситне стоке у кадилуку Ужице 1596. године, Мешовита грађа, miscellaneа, нова серија къ. XLI: 31-52.

Арсић, Р. 2011. Функција римске војне инфраструктуре на простору северозападне Србије. Гласник Српског археолошког друштва 27: 60-82.

Арсић, Р., Чебашек, Е., Ђенић, Ђ., Павловић, Н., Пецикоза, В. 2019. Јеринин град Бранговић. Ваљево: Народни музеј Ваљево, Завод за заштиту споменика културе Ваљево.

Булић, Д. 2016. Археолошка истраживања локалитета Гробљице у Косјерићу, Гласник Српског археолошког друштва 32: 183-204.

Васовић, М. 2003. Подрињско-ваљевске планине. Ваљево: Агенција Ваљевац, Ваљевска гимназија, Истраживачка станица Петница.

Vojnogeografski institut, 1972, Valjevo 4-3 broj lista: 478-4-3 (Seča Reka), 1:25.000, Beograd: Vojnogeografski institut.

Danilović, B., Filipović, V., Petrović, T. 1995. Kamena kugla na Mravinjcima, Petničke sveske 41: 302-315. Valjevo: Istraživačka stanica Petnica.

Зечевић, Е. 2005. Мраморје: стећичи у западној Србији. Београд: Српско археолошко друштво.

Исаиловић, М. 1989, Ваљево и околне области у средюем веку. Ваљево: Народни музеј; „Милић Ракић”; СИЗ друштвених делатности.

Ivanišević, V., Kazanski, M. 2007. Nouvelle nécropole des grandes migrations de Singidunum, Старинар LVII: 113-135.

Јеж, Ж., Старовић, А. 1994. Археолошки локалитети и налазишта у ваљевском крају. Ваљевац. Велики народни календар за просту 1994: 369-381. Ваљево: Ваљевац.

Ковачевић-Мајкић, J. 2009. Хидрографска студија реке Скрапеж. Београд: Географски институт „Јован Цвијић” САНУ, Српско географско друштво.

Лома, А. 1997. Прилог трагању за античким коренима Ваљева, Гласник 31: 5-36.

Максимовић, М. и Војновић, М. 2017. Путне везе Ужица са Полимљем и Подриюем (14-17. век), Ужички зборник 41: 39-72.

Милинковић, М. 2015. Рановизантијска насеља у Србији и њеном окружењу, Београд: Досије студио.

Милинковић, М. ур. 2017. Градина на Јелици, утврђени центар у Илирику VI век и вишеслојно археолошко налазиште, каталог изложбе, Београд Српска академија наука и уметности; Чачак Народни музеј Чачак.

Morača, М. 1962. Ratni dnevnik, Beograd: Vojno delo.

Мркобрад, Д. и Арсић, Р. 2004. Бранговић - Прелиминарна археолошка истраживања раносредњовековног утврђења (VI-X век). Гласник 38: 79-101.

Mrkobrad, D. 1980. Arheološki nalazi seobe naroda u Jugoslaviji. Beograd: Savez arheoloških društava Jugoslavije; Muzej grada Beograda.

Општина Косјерић 2018. Стратегија одрживог развоја општине Косјерић 2018-2028. Павловић, Љ. 1907. Колубара и Подгорина, Српски етнографски зборник 8, Насеља српских земаља IV: 345-1085. 
Павловић, Љ. 1925. Ужичка Црна Гора, Српски етнографски зборник 34, Насеља српских земаља 19: 1-191.

Павловић, 3. 2016. Ороними Србије. Трећи део Р-Т, Ономатолошки прилози XXIII: 113-292. Београд: САНУ.

Petković, S., Miladinović-Radmilović, N. 2014. Military graves from the Late Roman necropolis at Slog in Ravna (Timacum Minus), Старинар LXIVII: 87-130.

Ршумовић, P. 1980. Геоморфологија слива Скрапежа - положај и морфолошке целине, Зборник радова 33: 127-156. Београд: Географски институт „Јован Цвијић” CAHУ.

Vujović, M. 1998. Naoružanje i oprema rimskog vojnika u Gornjoj Meziji i jugoistočnom delu Panonije, Magistarska teza, Univerzitet u Beogradu.

Цвјетићанин, Т. 2016. Касноримска керамика Бердапа, Београд: Народни музеј.

Шкриванић, Г. 1974, Путеви у средњовековној Србији. Београд: Новинско издавачко предузеће „Туристичка штампа”.

Špehar, P. 2010. Materijalna kultura iz ranovizantijskih utvrđenja u Đerdapu, Beograd: Arheološki institut. 


\section{Dejan Bulić}

Institute of History, Belgrade

Radivoje Arsić

Cultural Monument Protection Institute, Valjevo

\section{DONJI TAOR - THE FORTIFICATION AND THE CHURCH}

Keywords: Taor, Valjevo, Western Serbia, Skrapež, Povlen, church, fortification, Older Iron Age, Early Byzantine period, tufa mine

In the area of the village of Taor, archaeological trench excavations were performed in 2019 of a smaller fortification on the hill of Mali Kik. That same year, research began of a church as well, located on a ridge at the bottom of the hill, beneath the fortification, and in the following year, in 2020, a complete archaeological research of it was performed.

The church is a one-nave building, with dimensions of $10.80 \times 6.40 \mathrm{~m}$; the preserved height of the walls was up to $1.15 \mathrm{~m}$ and their thickness $0.60-0.80$ $\mathrm{m}$. Out of the original three entrances into the church, the northern entrance was later walled up. Inside the apse, a subselium was registered, as well as a place for the episcopal cathedra. The absence of remains of a roof cover indicates a wooden roof, while the semi-calotte of the apse was made of blocks of tufa.

Inside the church, three grave burials were registered, piercing the mortar floor (graves no. $1 / 20-03 / 20$ ). The most interesting one is the third, an undoubtedly Christian grave, with an unusual orientation, N-S. It was apparently more important that the deceased be buried inside the church than the actual orientation of the grave. The material used for the church was limestone, taken from the same area, while the blocks of tufa came from the famous mines near Taorsko Vrelo.

According to the manner in which certain elements of the church were made, it corresponds to the manner of building of the Early Byzantine period in the territory of western Serbia.

Archaeological research activities of the fortification showed two cultural horizons - a more recent one, from the Late Antique / Early Byzantine period, and an older one, from the period of the Older Iron Age. The building of the watchtower is placed into the Late Antiquity, while the time of the destruction of the fortification was contemporary to the destruction of the church, in the Early Byzantine period, in the end of the $6^{\text {th }}$ or the beginning of the $7^{\text {th }}$ century. 
The similarity of the archaeological material from the church and the fortification merely indicate their chronological synchronicity. The fortification at Taor can be seen, first and foremost, in the context of the road network, along the route of which there were several fortifications with a cultural horizon from the Older Iron Age and the Late Antique / Early Byzantine stratum, often with a horizon from the Early Middle Ages as well. The road led from the valley of the Kolubara and Valjevo up to Lelić and the fort on the hill of Ćelijsko Brdo, then through the canyon of the Gradac, along the fortification at Brangović. The road to Povlen was probably forking, with one fork leading to the valley of the Drina, while the other lead through Paramun and Zlostup, along Karane towards Užice and onwards, and from this route another fork lead to Požega and Čačak as well. In time, this communication lost its importance. Even though it was a peripheral road, however, it wasn't completely neglected, as confirmed by its being in use even today.

We can conclude that the fortress was destroyed along with the church. It is most probable that this area was abandoned or that a non-Christian population was settled there, which is why a restoration of the church never occurred, and the tradition of the existence of a sacral place was lost. The last members of the original population, perhaps members of the founder's family, were buried inside the church, soon after it was destroyed. 

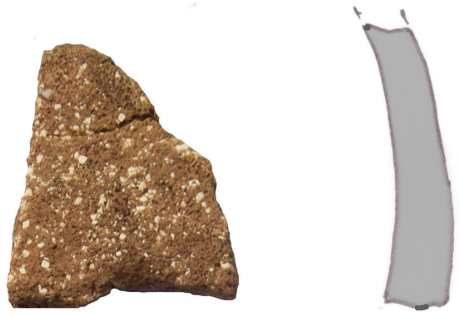

2.

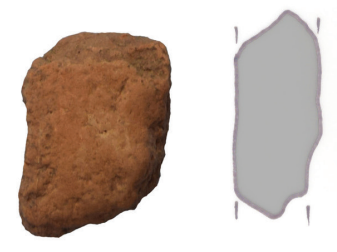

3.
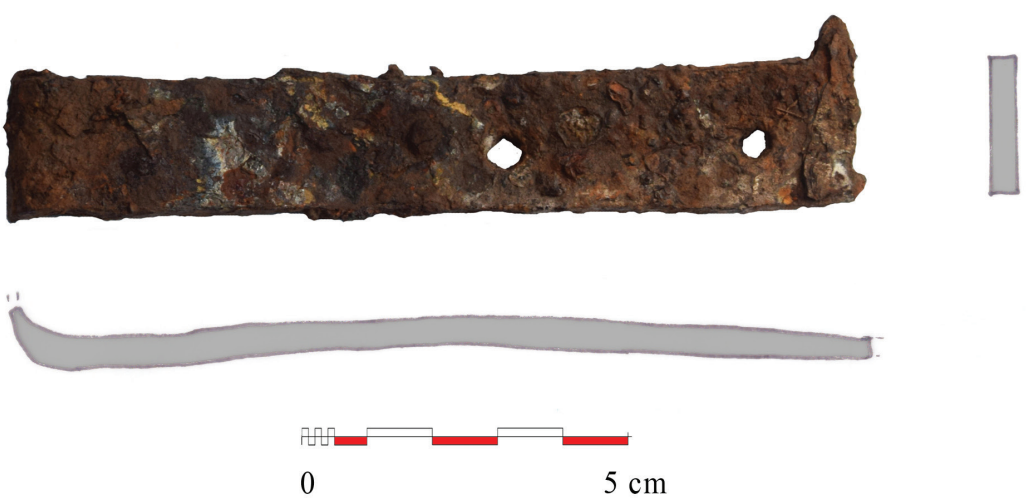

4.

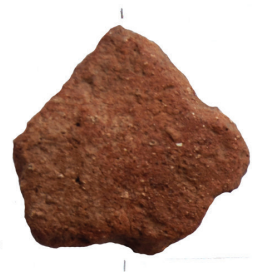

6.

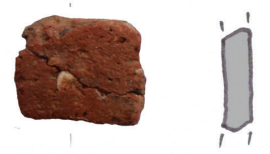

8.

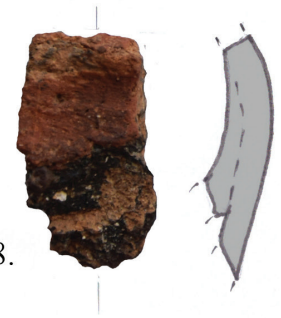

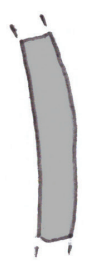

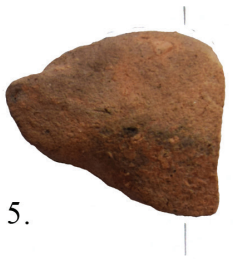

7.

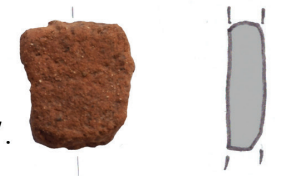

9.

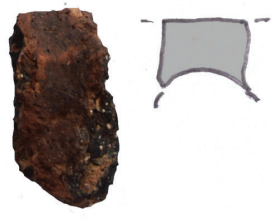

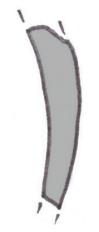

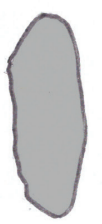

T. I Град-Таор: 1-3: Површински налази; 4-9: Сонда 2/19, слој црвеномрке земље Pl. I Grad-Taor: 1-3: Surface finds; 4-9: Trench 2/19, layer of red-brown earth 
1.

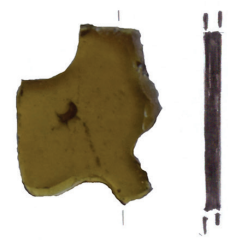

2.

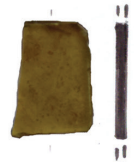

3.

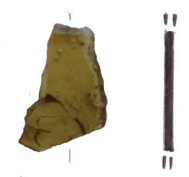

4.
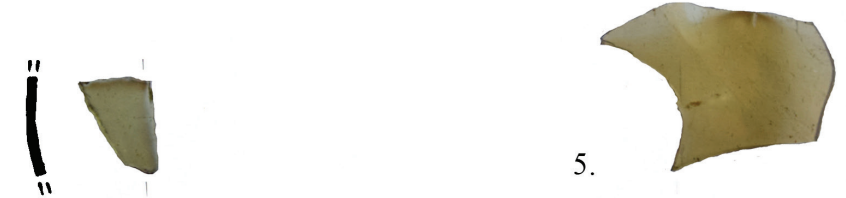

6

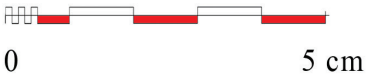

8.

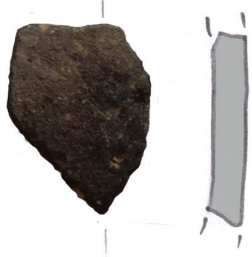

7.

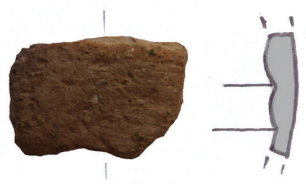

9.

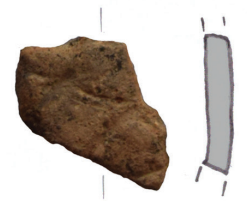

10.

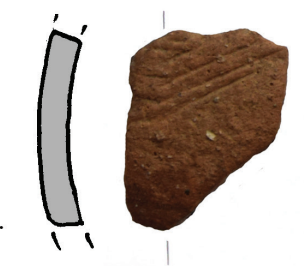

5.
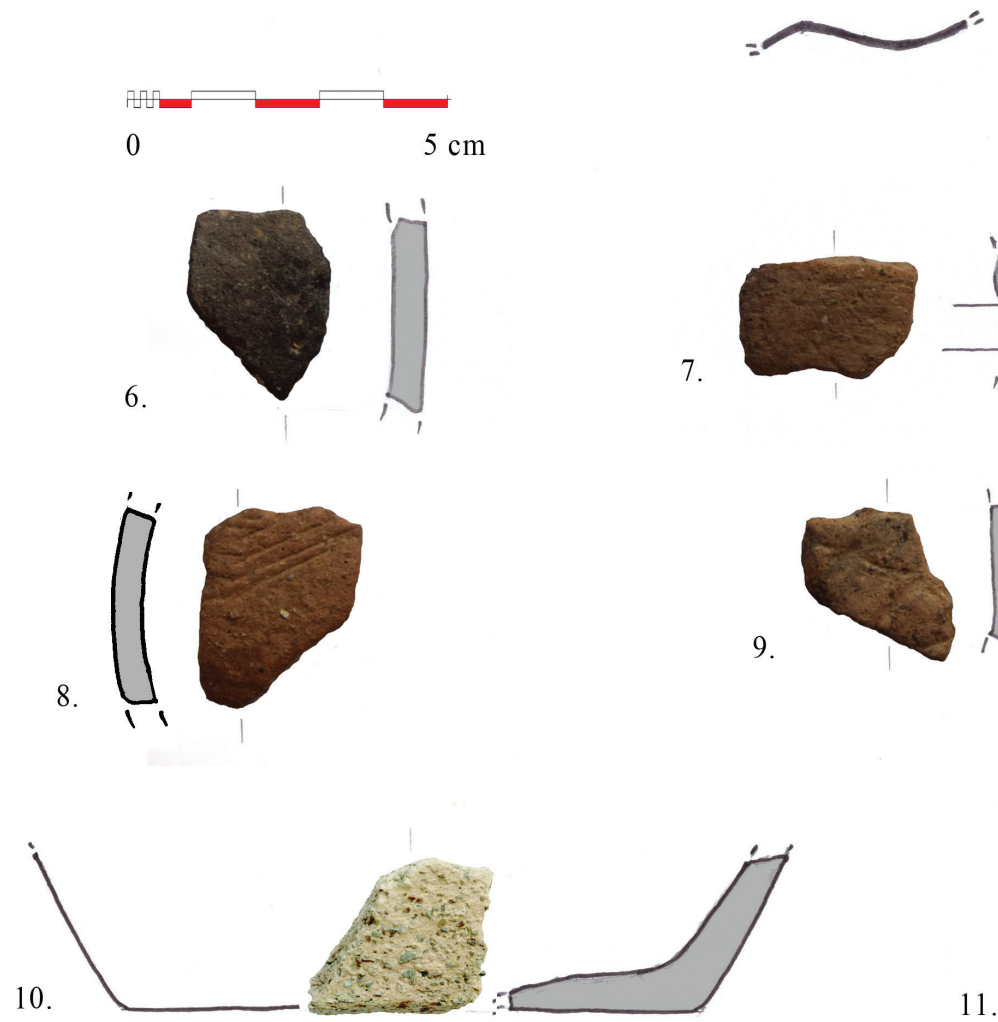

11.
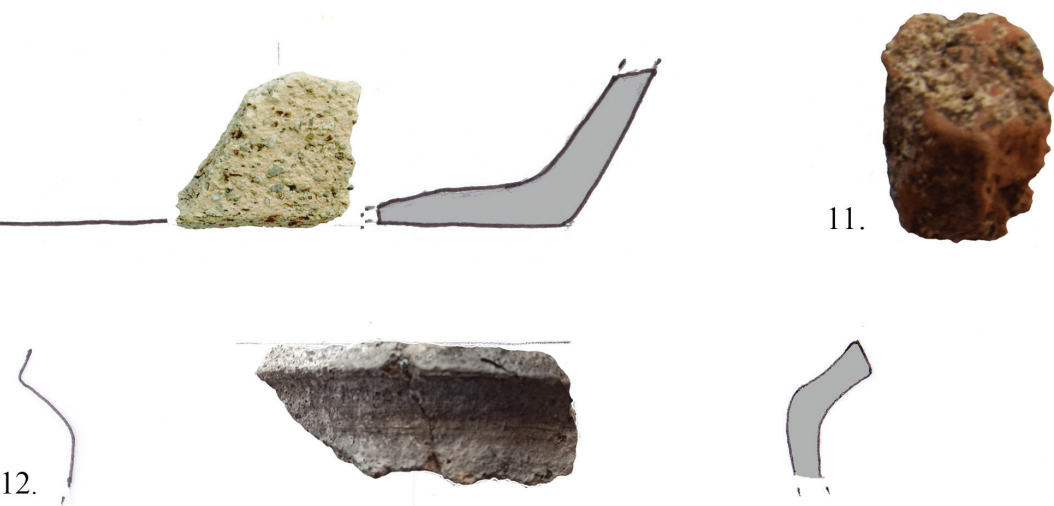

T. II Град-Таор: 1-11 Сонда 2/19, слој сивомрке земље

Pl. II Grad-Taor: 1-11 Trench 2/19, layer of grey-brown earth 
1.

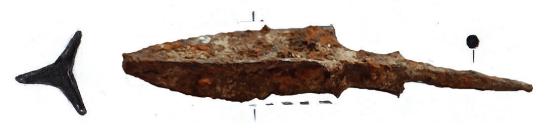

2 .

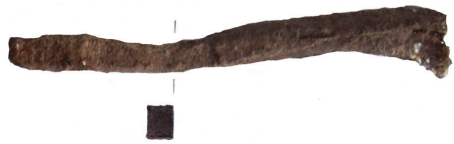

4.

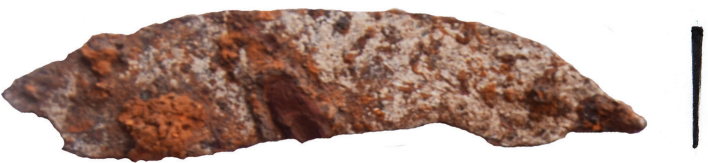

3.
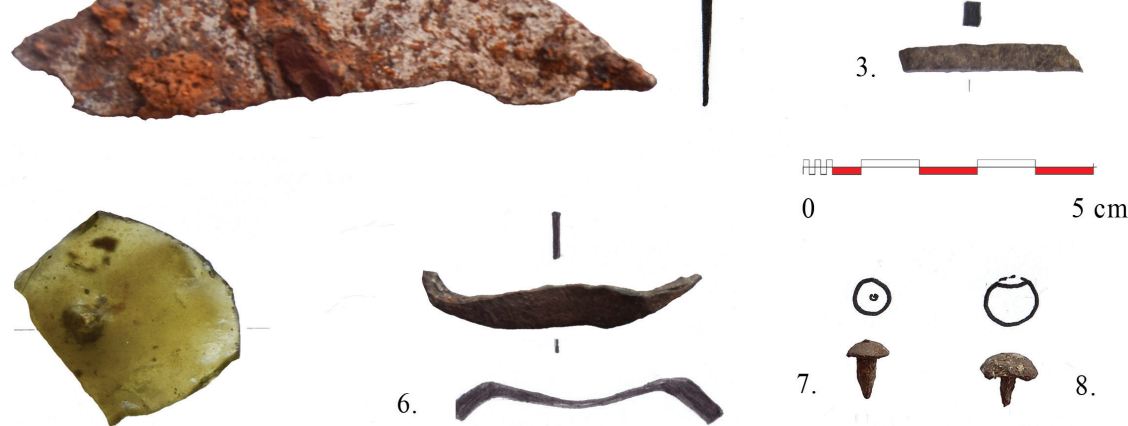

6.

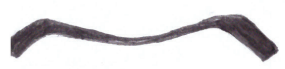

7. 18

9.
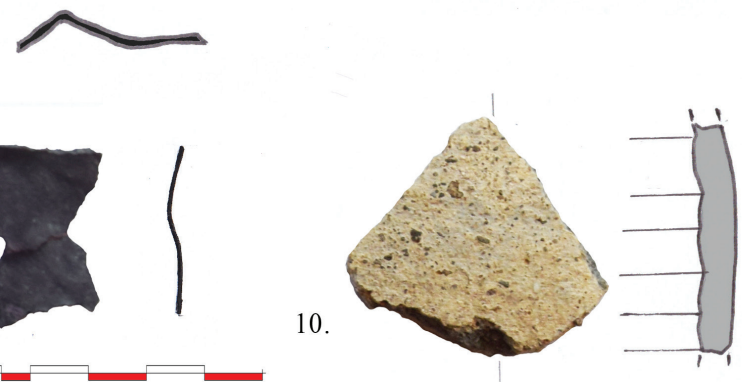

11.
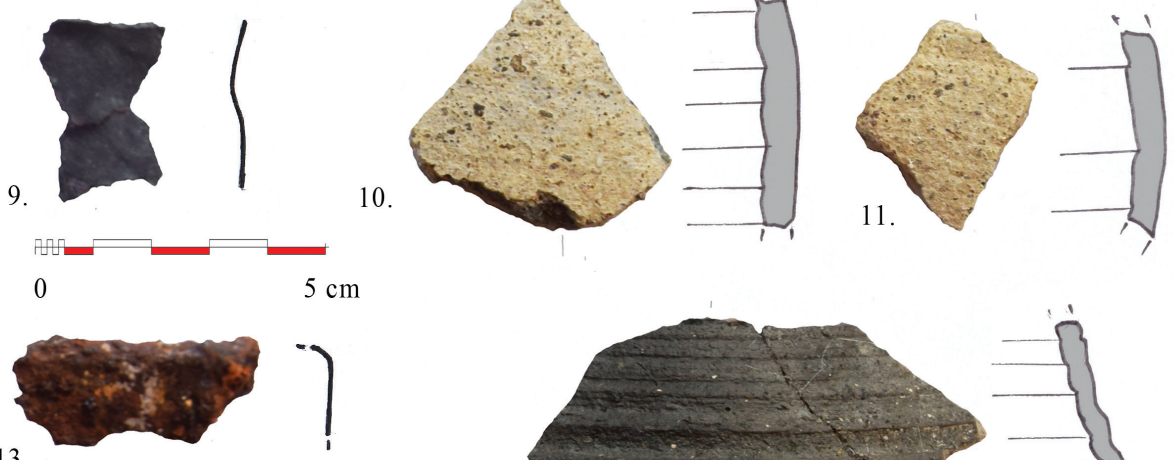

13.
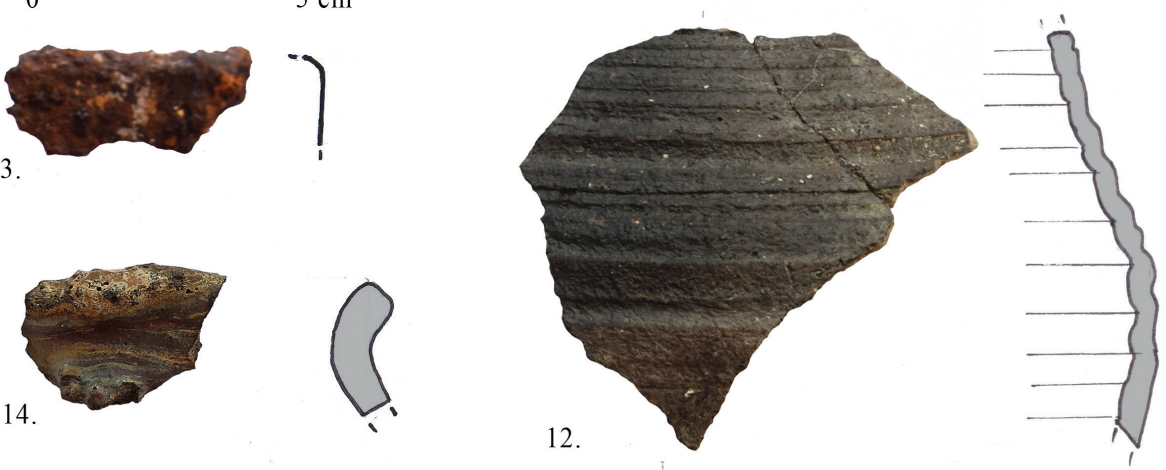

T. III Налази из цркве, 1-7; 9-12: слој шута; 8: избачена земља;

13-14: тамномрка земља

PI. III Finds from the church, 1-7; 9-12: rubble layer: 8; removed earth; 13-14: dark-brown earth 